\title{
Increased Expression of the NG2 Chondroitin-Sulfate Proteoglycan after Brain Injury
}

\author{
Joel M. Levine \\ Department of Neurobiology and Behavior, SUNY at Stony Brook, Stony Brook, New York 11794
}

Injury to the adult mammalian CNS results in reactive changes among the glial cells surrounding the site of damage. Recently, an unusual class of glial cells has been identified within the intact adult rat cerebellum on the basis of the expression of the NG2 chondroitin-sulfate proteoglycan (Levine and Card, 1987). To determine whether the cells that express the NG2 proteoglycan show reactive changes after injury, small puncture lesions were made into the cerebelli of adult rats, and changes among astrocytes, microglia and NG2-positive cells were examined using immunohistochemical staining with cell type-specific marker antibodies. Beginning at $\mathbf{2 4} \mathrm{hr}$ after lesion, NG2-positive cells immediately adjacent to the lesion site bound the anti-NG2 antibodies more heavily than cells within the undamaged areas of the cerebellum. This increase in anti-NG2 immunoreactivity was transient, reaching a maximum at $7 \mathrm{~d}$ postlesion and declining slowly thereafter. The increase in anti-NG2 immunoreactivity was accompanied by an increase in the levels of mRNA encoding the NG2 core protein as demonstrated by in situ hybridization. NG2-positive cells adjacent to the lesion site incorporated ${ }^{3} \mathrm{H}$-thymidine into their nuclei beginning at $24 \mathrm{hr}$ postlesion and increased in number. Concurrent with these changes, microglia became activated and increased in number, monocytes invaded the damaged tissue, and an astrocytic scar formed. These observations demonstrate that the cells that express the NG2 proteoglycan are a reactive cell type that responds to brain injury. The increased expression of the NG2 chondroitin-sulfate proteoglycan may contribute to the failure of damaged CNS axons to regenerate successfully.

[Key words: O2A progenitor cells, chondroitin-sulfate proteoglycan, astrogliosis, CNS injury]

Axons of the mammalian CNS have only a limited capacity to regrow after injury. This is in contrast to axons of the PNS which can regenerate successfully after injury. The elegant studies of Aguayo and collaborators (David and Aguayo, 1983) have demonstrated that CNS neurons are not intrinsically incapable of regrowth after injury; rather, these studies suggest that the environment of the damaged CNS does not have the capacity

Received July 28, 1993; revised Feb. 3, 1994; accepted Feb. 16, 1994.

I thank A. K. Levine for technical assistance, Dr. W. Stallcup for his gift of NG2 cDNA clones, Dr. J. White for assistance with the in situ hybridization, Dr. W. Theurkauf for the use of a confocal microscope, and Drs. J. Cabot and A. Bicknese for comments on the manuscript. This work was supported by Grant NS21 198 from the National Institutes of Health.

Correspondence should be addressed to Dr. Joel I evine at the above address. Copyright (C) 1994 Society for Neuroscience $0270-6474 / 94 / 144716-15 \$ 05.00 / 0$ to support extensive axonal growth. A major problem in neurobiology is to understand the cellular and biochemical features of the damaged CNS that may be responsible for the inability of this tissue to support axon regrowth.

Experimentally induced damage to the CNS leads to multiple changes in the glial cells surrounding the damaged tissue and the formation of a scar (Berry et al., 1983; Reier et al., 1983). Principal among these changes is an hypertrophy and hyperplasia of the astrocytes surrounding the injured tissue. Immunocy tochemical and autoradiographic studies have demonstrated that astrocytes within damaged tissue display increased immunoreactivity for glial fibrillary acidic protein (GFAP), the intermediate filament protein of astrocytes, and become mitotically active (Cavanagh, 1970; Latov et al., 1979; Mathewson and Berry, 1985; Miyake et al., 1988, 1992; Takamiya et al., 1988; Topp et al., 1989). Part of the increase in GFAP immunoreactivity within damaged tissue is likely due to the increased expression of this protein by glial cells that normally have little or no immunocytochemically detectable GFAP.

In addition to these astrocytic changes, microglial cells within damaged tissue become activated (for review, see Streit et al., 1988). This activation includes cell proliferation and a change from a ramified to an ameboid morphology. Activated microglia are the major phagocytotic cells within damaged areas of the CNS and are thought to remove cellular debris.

When brain injury includes damage to the blood-brain barrier, there is an infiltration of monocytes from the circulation into the brain parenchyma (Giulian et al., 1989). These cells also carry out phagocytotic functions within damaged tissue and promote wound healing.

In addition to astrocytes, oligodendrocytes and microglia, several studies have identified glial cells that do not fall easily into these major categories. For example, Vaughn and Peters (1968) described a glial cell in the developing and adult rat optic nerve lacking in intermediate filaments and microtubules. They suggested that this cell might be a multipotential stem cell. Reyners et al. (1982, 1986) described a glial cell of the adult rat cerebral cortex (the beta astrocyte) also lacking intermediate filaments that was distinguishable from oligodendrocytes and microglia at the ultrastructural level. This cell type became labeled with silver grains after administration of ${ }^{3} \mathrm{H}$-thymidine to adult rats suggesting that the beta astrocyte is a glial progenitor cell. Levine and Card (1987) used antibodies against the NG2 proteoglycan (NG2 PG) to identify and characterize a glial cell of the adult rat cerebellar cortex that did not display ultrastructural features of either fibrous astrocytes or oligodendrocytes. Morphologically similar cells have been observed in the adult rat cerebral cortex (Stallcup et al., 1983). Lastly, Fulton et al. (1992) used quisqualate stimulated cobalt uptake to identify a glial cell in 
the young postnatal and adult rat optic nerve that had similar morphological features to the cells described above. It has been suggested (Fulton et al., 1992; Levine, 1993) that these unusual glial cells may correspond to the $\mathrm{O} 2 \mathrm{~A}^{\text {adult }}$ progenitor cell, a cell type that has been studied extensively in cell culture (Wolswijk and Noble, 1989; Wolswijk et al., 1991; Wren et al., 1992).

The functions of these unusual glial cells are unknown. To begin to characterize the functional properties of the NG2-positive glia, the question of whether this cell type participates in the reactions to brain injury was asked. After puncture lesions of the adult cerebellum, there is a rapid and transient upregulation of the expression of the NG2 PG. Cells carrying this cell surface marker incorporate ${ }^{3} \mathrm{H}$-thymidine and increase in number. These studies demonstrate that NG2-positive glial cells participate in the glial reaction to brain injury.

\section{Materials and Methods}

Surgicul procedures. Sprague-Dawley rats (greater than 3 months of age) of either sex were used throughout this study. The animals were maintained in a $12 \mathrm{hr}$ light/dark cycle with free access to food and water. Animals were anesthetized with a mixture of ketamine $(9 \mathrm{mg} / 100 \mathrm{gm}$ body weight $)$ and xylazine $(1 \mathrm{mg} / 100 \mathrm{gm}$ body weight) and, under aseptic conditions, a small burr hole was drilled through the skull over the cerebellum and a 27 gauge needle was inserted obliquely through the pia to a depth of $2-3 \mathrm{~mm}$. Between two and four penetrations were made into a single hurr hole in each animal. Bleeding was minimal. The hole was filled with Gelfoam and the wound closed with either sutures or stainless steel clips. The animals were kept warm during recovery and returned to the animal housing facility. The animals showed no obvious behavioral or motor deficits after recovery.

Histological and autoradiographic procedures. At varying intervals after surgery $(1,2,4,5,7,10,15,30$, and $56 \mathrm{~d})$, the animals were again anesthetized as described above and perfused intracardially with 300 $\mathrm{ml}$ of warm saline followed by $900 \mathrm{ml}$ of $4 \%$ freshly depolymerized paraformaldehyde in $0.1 \mathrm{~m}$ phosphate buffer, $\mathrm{pH} 7.2$. Age-matched control animals that either had no surgical manipulation or whose cerebelli were surgically exposed but not lesioned were perfused similarly. The brains were removed, postfixed for $3 \mathrm{hr}$ at $4^{\circ} \mathrm{C}$ and cryoprotected by immersion in $30 \%$ sucrose, $0.02 \%$ sodium azide at $4^{\circ} \mathrm{C}$ for $48-72$ hr. For pulse-lahel autoradingraphy, animals at $1,2,5$, and $7 \mathrm{~d}$ postlesion, were given two intraperitoneal injections of ${ }^{3} \mathrm{H}$-thymidine (ICN; $28 \mathrm{Ci} / \mathrm{mmol}, 5 \mu \mathrm{Ci} / \mathrm{gm}$ body weight) over a $2 \mathrm{hr}$ period and were anesthetized and killed by perfusion $2 \mathrm{hr}$ after the second injection. For pulse-chase autoradiographic studies, animals at 1 and 2 d postlesion were injected with ${ }^{3} \mathrm{H}$-thymidine as described above and allowed to survive for 30 additional days before death. Thirty micrometer frozen sections were cut in the sagittal plane and processed as freely floating sections. Tissue antigens were localized with the antibodies described below using a Vectastain Elite Kit (Vector Labs) as described previously (Levine and Card, 1987). When the primary antibodies were omitted from the staining procedures, there was no staining of cellular elements within either normal or lesioned tissue. Autoradiography was carried out as described previously (Levine et al., 1993). In the cases used for double-label immunofluorescent studies, tissue blocks were embedded in OCT (Miles), frozen, and cryostat sectioned at $12 \mu \mathrm{m}$ in the sagittal plane. The immunofluorescent localization of multiple antigens was carried out as described previously (Levine and Card, 1987).

In situ hybridization. In situ hybridization was carried out using cRNA probes synthesized from NG2 encoding plasmid A1 1 (Nishiyama et al., 1991) obtained from Dr. W. Stallcup (La Jolla Cancer Research Institute, La Jolla, CA). The plasmid was linearized with Bgl II (Promega) and probes were synthesized using T3 polymerase (Promega) and ${ }^{35} \mathrm{~S}$ UTP (Amersham) according to manufacturer's protocols. The antisense cRNA probes had a specific activity of $9 \times 10^{8} \mathrm{cpm} / \mu \mathrm{g}$. Free floating sections were washed in $0.1 \mathrm{M}$ phosphate buffer containing $10 \mathrm{mM}$ glycine and incubated in $0.02 \mathrm{M} \mathrm{HCl}$ for $10 \mathrm{~min}$ at room temperature (RT). The sections were treated with proteinase $\mathrm{K}(1 \mu \mathrm{g} / \mathrm{ml}, 30 \mathrm{~min}$, $37^{\circ} \mathrm{C}$ ) washed in $2 \times$ saline-sodium citrate (SSC) and prehybridized for $60 \mathrm{~min}$ at $45^{\circ} \mathrm{C}$ in $50 \%$ formamide, $10 \%$ dextran sulfate, $35 \times$ Denhardt's, $115 \mu \mathrm{g} / \mathrm{ml}$ yeast tRNA, $300 \mu \mathrm{g} / \mathrm{ml}$ herring sperm DNA, and 20 $\mathrm{mm}$ dithiothreitol (DTT). Sections were hybridized for $16 \mathrm{hr}$ at $45^{\circ} \mathrm{C}$ in the same solution containing $10^{7} \mathrm{cpm} / \mathrm{ml}$ of the antisense $\mathrm{cRNA}$ probe.
Control sections were hybridized in a solution containing the radioactive probc and a 100 -fold excess of nonradioactive antisense probe cRNA. The sections were washed twice in $4 \times \mathrm{SSC}, 5 \mathrm{~mm}$ DTT at $45^{\circ} \mathrm{C}(30$ $\mathrm{min} /$ wash), digested with RNase $\mathrm{A}$, and washed in $2 \times \mathrm{SSC}$ at $40^{\circ} \mathrm{C}$, $0.5 \times \mathrm{SSC}$, and $0.1 \times \mathrm{SSC}$ all containing $5 \mathrm{~mm}$ DTT. After an overnight wash at room temperature in $0.1 \times$ SSC, $5 \mathrm{~mm}$ DTT, the sections were mounted on gelatin coated slides, dried, and exposed to $\beta$-Max autoradiography film (Amersham). The autoradiographic images were analyzed and digitized using an MCID image analysis system (Imaging Research, St. Catherine's, Ontario) as described previously (White et al., 1990).

Antibodies, analysis, and reagents. The preparation and specificity of a rabbit anti-NG2 antiserum and two monoclonal antibodies (D31.10 and D120.43) directed against different epitopes on the NG2 core protein has been described (Levine and Stallcup, 1987; Nishiyama et al., 1991). The rabbit antiserum was used at 1:250 for indirect immunofluorescence and the two monoclonal antibodies were used at 1:50 each for immunohistochemistry. In fluorescence studies, the rabbit antibody was visualized with a fluorescein isothiocyanate (FITC)-conjugated antirabbit antibody obtained from TAGO (Burlingame, CA) and the mouse monoclonal antibodies were visualized with a Texas red-conjugated anti-mouse antibody obtained from either Fisher or Jackson Labs. In double-label fluorescence studies, these antibodies bound to the same cell types in vivo and in vitro (unpublished observations). Monoclonal antibodies against GFAP were purchased from Boehringer-Mannheim and monoclonal antibodies EDI and OX 42 were purchased from Serotec. Measurements of distance and area were made using an imaging computer equipped with oPTIMAs software (Bioscan, Inc., Edmonds, WA). Laser scanning confocal microscopy was carried out with a Nikon Optiphot fluorescence microscope equipped with a Bio-Rad MRC 600 laser scanning confocal attachment. Unless specified, all other reagents were purchased from Sigma.

\section{Results}

To analyze changes among glial cells after CNS injury, small puncture lesions were made in the cerebelli of anesthetized, adult rats and at varying intervals after making the lesions, the animals were killed and the tissue prepared for immunohistochemistry.

\section{Changes in NG2 immunoreactivity after lesion}

Changes in the expression of the NG2 PG were analyzed by staining tissue sections with a mixture of two different monoclonal antibodies (D31.10 and D120.23) directed against different epitopes on the NG2 core protein (Levine, 1989; Nishiyama et al., 1991). The appearance of normal cerebellar tissue stained with these antibodies is shown in Figure 1, $A$ and $E$. As described previously (Levine and Card, 1987), the NG2 PG is expressed on the surface of a population of stellate-appearing cells distributed in a regular fashion throughout the cerebellar cortex.

At $1 \mathrm{~d}$ postlesion (dpl), the NG2-positive cells adjacent to the damaged tissue exhibited an increase in immunostaining intensity relative to cells lying within undamaged areas of the same tissue section (Fig. $1 B$ ). The cells that bound the anti-NG2 antibodies heavily had enlarged cell bodies and swollen processes (Fig. $1 F$ ). These morphological changes occurred only in cells immediately adjacent to the lesioned area; cells lying more than $100 \mu \mathrm{m}$ from the lesion appeared normal. The confinement of these morphological changes to cells immediately adjacent to the lesion suggests that the changes are due to direct physical damage of the cells.

At $2 \mathrm{dpl}$, densely staining, large round cells appeared at the borders of the lesion (Fig. $1 C, G$ ). Intermixed with these cells were process bearing cells with swollen cell bodies and enlarged processes similar to those observed at $1 \mathrm{dpl}$. As was the case at $1 \mathrm{dpl}$, the morphologically altered cells were found only at the horders of the lesion; NG2-positive cells lying more than 100 $\mu \mathrm{m}$ from the lesion site appeared normal. 

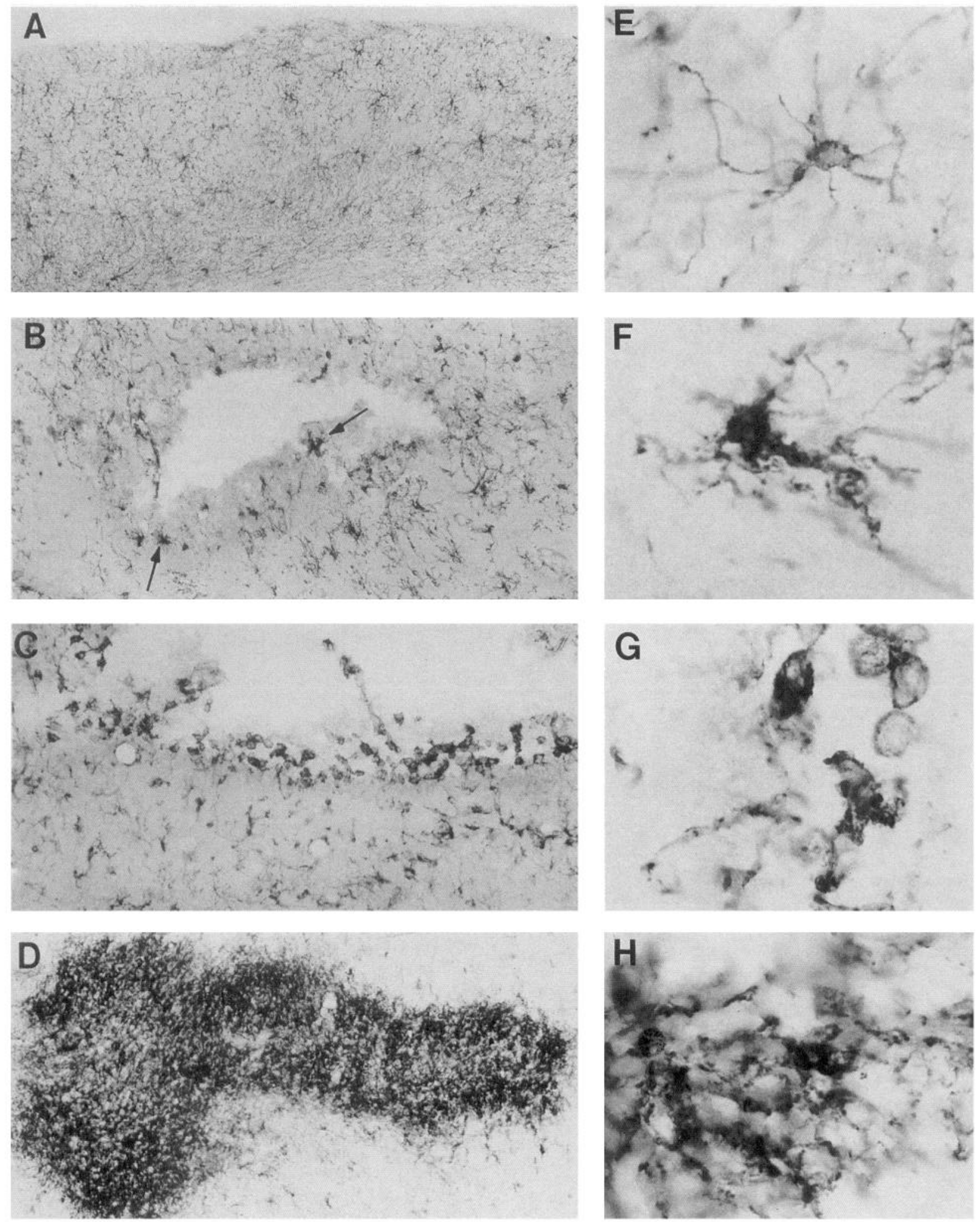

Figure 1. Appearance of NG2 immunoreactivity in normal and lesioned cerebellum. $A-D$, Low-power photomicrographs $(97 \times)$ of normal and lesioned cerebellum. $A$, Normal cerebellum, NG2-expressing glial cells are distributed evenly throughout the cerebellar cortex. $B$, Twenty-four hours postlesion. Most NG2-positive cells appear normal. A few densely labeled cells with swollen cell bodies and processes lie close to the puncture lesion (arrows). C, Forty-eight hours postlesion. Densely immunoreactive, large round cells appear at the border of the lesion cavity. $D$, Seven days postlesion. A dense plaque of immunoreactive cells and processes surrounds the puncture site. $E-H$, High-power photomicrographs $(758 \times)$ of individual NG2-expressing cells in normal and lesioned cerebellum. $E$, A single NG2-expressing cell in normal cerebellar molecular layer. This cell has a characteristic stellate appearance. $F, 24 \mathrm{hr}$ postlesion. This cell has an enlarged cell body and a single swollen process. $G$, The border of a lesion at $48 \mathrm{hr}$. Large round, NG2-positive cell bodies. $H$, Seven days postlesion cerebellum. Heavily labeled processes with short branches ramify throughout the area surrounding the lesion. 

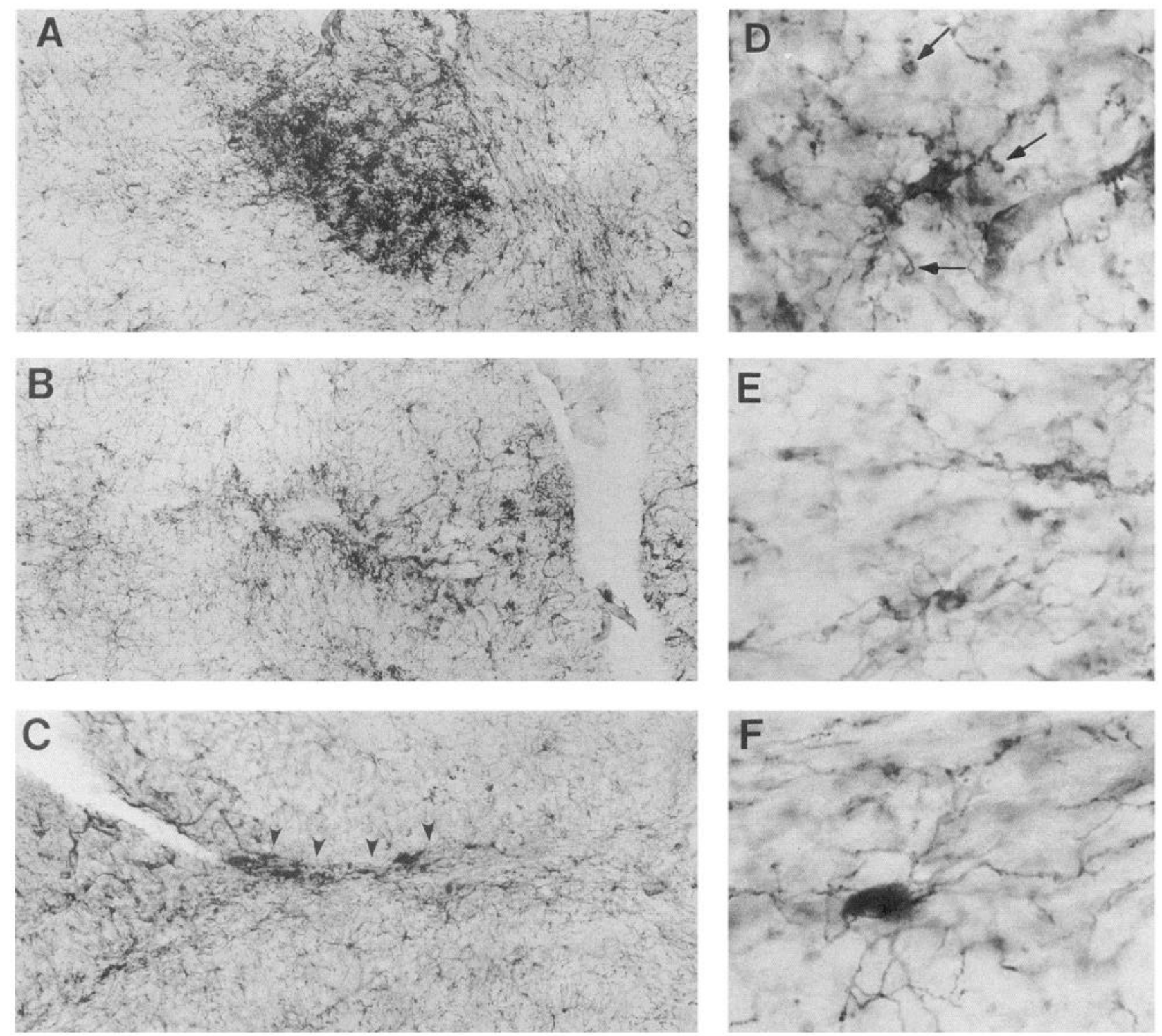

Figure 2. Appearance of NG2 immunoreactivity in lesioned cerebellum. A, Fifteen days postlesion. The density and extent of NG2-immunoreactivity in the area of the lesion is reduced relative to $7 \mathrm{~d}$ postlesion (Fig. $1 D$ ). $B$, Thirty days postlesion. Heavily labeled cells are found only adjacent to the lesion cavity. $C$, Fifty-six days postlesion. The needle track is apparent by the increased density of immunopositive processes oriented parallel to the lesion (arrowheads). D, A single NG2-positive cell at $15 \mathrm{~d}$ postlesion with an enlarged cell body. The arrows point to beaded profiles. $E$, Thirty days after lesion. The two cells shown have a normal morphology with processes oriented parallel to the needle track. $F$, Fiftysix days after lesion. This cell, which is located within the scar, is morphologically indistinguishable from NG2-positive cells of normal cerebellum although the cell body is heavily stained (e.g., see Fig. $1 E$ ). Magnification: $A-C, 97 \times ; D-F, 758 \times$.

Beginning at 4-5 dpl, there was a dramatic increase in the intensity and extent of NG2 immunoreactivity surrounding the puncture wound (see Fig. $3 C, 6 E$ ). Numerous cell bodies and highly ramified processes appeared in the region immediately surrounding the lesion site. The density and intensity of NG2 immunoreactivity continued to increase over the next $3 \mathrm{~d}$ so that by $7 \mathrm{dpl}$, there was a dense plaque of immunoreactivity surrounding the lesion site (Fig. $1 D$ ). This plaque consisted of heavily stained cell bodies and processes. Although individual NG2-expressing cells were difficult to resolve within this region, heavily labeled cells appeared to give rise to short processes which often had a beaded and varicose appearance (Fig. $1 H$ ). These processes appeared to ramify around other cellular elements of the forming glial scar (e.g., see Fig. 7). As was the case with shorter postlesion survival times, the increases in NG2 immunoreactivity were confined to the damaged tissue; elsewhere in the cerebellum, NG2-positive cells appeared normal.

Between $10-15 \mathrm{dpl}$, NG2 immunoreactivity began to decline within the area adjacent to the lesion site. Although glial plaques exhibiting high levels of NG2 immunoreactivity were still apparent at $15 \mathrm{dpl}$ (Fig. $2 A$ ), both the size of the plaques and the intensity of staining within the plaques was reduced relative to the $7 \mathrm{dpl}$ survival times. Individual cells within the plaques were stellate shaped with long, branched processes (Fig. 2D). In addition, many beaded immunoreactive processes were found within the glial plaques.

The intensity and density of NG2 immunoreactivity continued to decline over the next 2-5 weeks. At $30 \mathrm{dpl}$, the plaque 

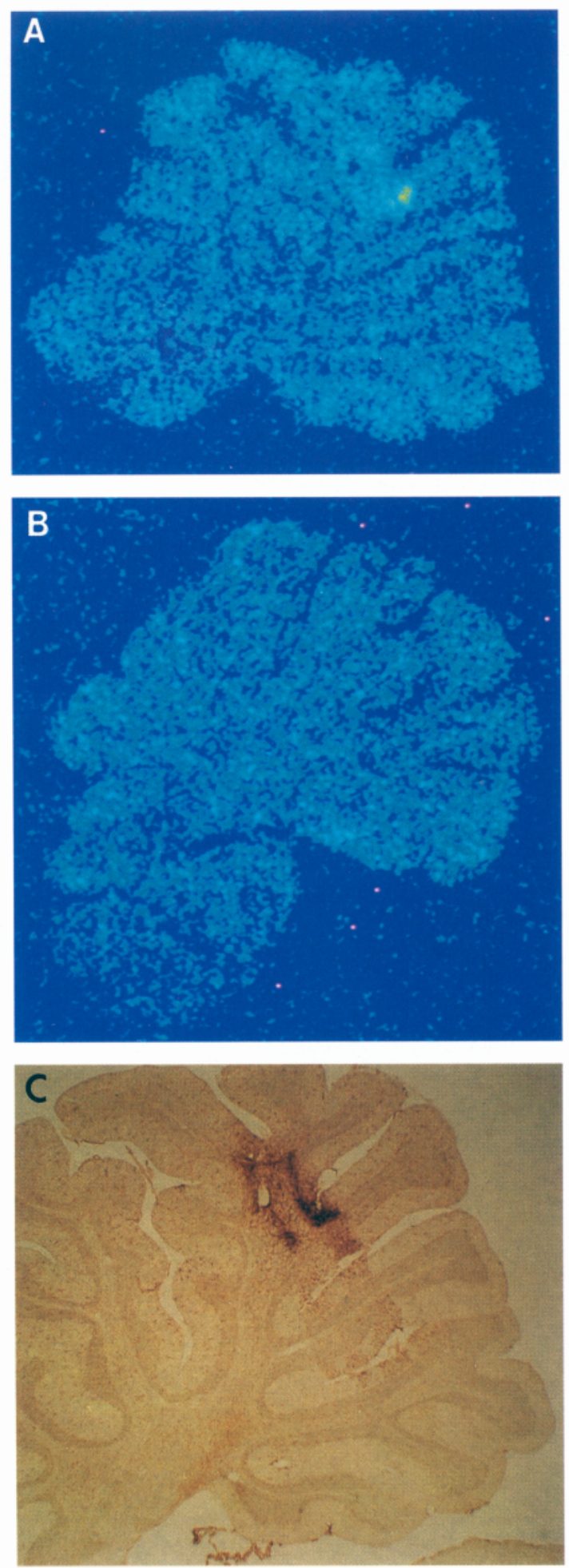

Figure 3. Localization of NG2 encoding mRNA by in situ hybridization. In situ hybridization to tissue sections from an animal lesioned 4 $\mathrm{d}$ prior to death was carried out as described in Materials and Methods. $A$ and $B$ are digital images prepared using an MCID image analysis system. $A$, In situ hybridization to lesioned cerebellum. There is increased binding of the labeled probe to the lesion site. $B$, A control section that was incubated in labeled probe plus a 100-fold excess of unlabeled probe. Under these conditions, the unlabeled probe competes for the binding of the labeled probe. Consequently, there is no specific signal at the lesion site. $C, \mathrm{~A}$ portion of an adjacent section that was immunohistochemically stained to reveal the distribution of the NG2 PG. The area showing increased levels of NG2 specific mRNA in $A$ is coincident with the heavily stained area in $C$. of anti-NG2 immunoreactivity had disappeared and only a few, densely stained cells remained surrounding the lesion site (Fig. $2 B$ ). The processes of these cells were often oriented parallel to the needle track (Fig. 2E). At $56 \mathrm{dpl}$, the longest postlesion interval studied, the lesion sites could be identified on the basis of a slightly increased density of anti-NG2-labeled cells and processes (Fig. 2C). Individual NG2-positive cells at the lesion site were indistinguishable in their morphology from those cells found in normal cerebellum (Fig. $2 F$ ).

To estimate the linear extent of tissue displaying increased immunoreactivity for the NG2 PG, we measured the longest and shortest distances from the edge of the lesion cavity to the distal edge of the annular zone displaying increased immunoreactivity for the NG2 PG. At $5 \mathrm{dpl}$, the longest distance was $291 \pm 77 \mu \mathrm{m}($ range $=176-436 \mu \mathrm{m})$ and the shortest distance was $56 \pm 15 \mu \mathrm{m}$ (range $=27-73 \mu \mathrm{m})$. At $7 \mathrm{dpl}$, the longest distance had increased slightly but not significantly to $311 \pm$ $28 \mu \mathrm{m}$ (range $=255-345 \mu \mathrm{m})$ while the shortest distance was $51 \pm 16 \mu \mathrm{m}($ range $=28-73 \mu \mathrm{m})$. Since the plane of tissue section was not always perpendicular to the angle at which the needle penetrated the tissue, absolute values for the area of tissue displaying increased anti-NG2 immunoreactivity cannot be extracted from these measurements. Nevertheless, these measurements suggest that NG2-positive cells lying within $300 \mu \mathrm{m}$ from a site of focal damage display reactive changes to that damage. Cells lying greater than $400 \mu \mathrm{m}$ from a site of damage retain their normal morphological features.

\section{In situ hybridization}

The data presented in Figures 1 and 2 demonstrate that NG2 immunoreactivity transiently increases after a puncture lesion. Proteoglycans such as NG2 can be secreted or shed from the cell surface. Thus, it is possible that some of the increased immunoreactivity described above could be due to the synthesis of the NG2 PG at sites removed from the local region of the lesion. Since the puncture lesions employed here directly damage the blood-brain barrier, circulating molecules would have access to the damaged tissue where they could bind to the surfaces of cells. To determine whether injury leads to increased levels of mRNAs encoding the NG2 core protein at the lesion site, tissue prepared at $4 \mathrm{dpl}$ was subjected to in situ hybridization to reveal the distribution of NG2 encoding mRNAs as described in Materials and Methods. Figure $3 A$ shows that puncture injury is accompanied by a highly localized increase in levels of NG2 encoding mRNAs. Figure $3 B$ is a control section that was incubated in labeled probe plus a 100 -fold excess of unlabeled probe. Under these conditions, the specific signal seen in Figure $3 \mathrm{~A}$ disappears. The area of tissue displaying increased levels of NG2 mRNA is coincident with the area displaying increased NG2 immunoreactivity (Fig. $3 C$ ). Thus damage to the CNS leads to an increase in mRNAs encoding the NG2 core protein in the tissue immediately adjacent to the damage.

\section{Autoradiographic analysis}

The increases in both the expression of the NG2 PG and the number of cells expressing the NG2 PG after injury suggest that this population of glial cells may be stimulated to divide by the injury. To examine this possibility directly, animals were given two injections of ${ }^{3} \mathrm{H}$-thymidine over a $4 \mathrm{hr}$ period at $1,2,5$, and $7 \mathrm{~d}$ after lesioning and the cerebellar tissue was prepared for immunohistochemistry and emulsion autoradiography as described in Materials and Methods. As shown in Figure 4A, 

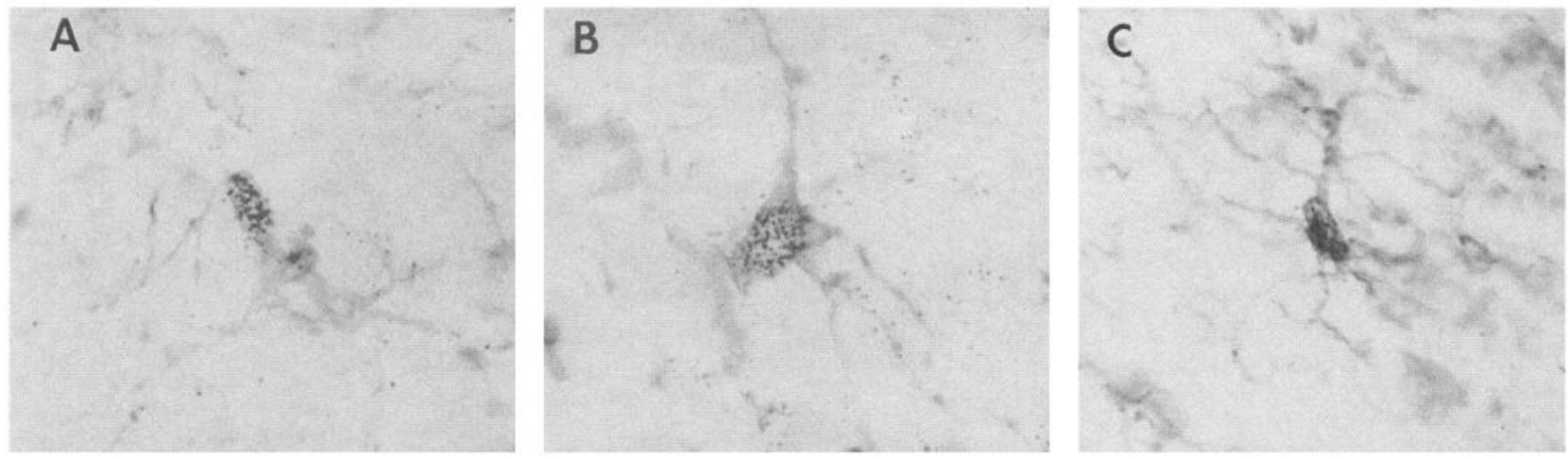

Figure 4. NG2-positive cells incorporate ${ }^{3} \mathrm{H}$-thymidine into their nuclei after lesion. Lesioned animals were pulse-labeled with ${ }^{3} \mathrm{H}$-thymidine and processed for autoradiography and immunohistochemistry with the anti-NG2 antibodies as described in Materials and Methods. A, A silver grainlabeled NG2-positive cell from an animal that was injected with ${ }^{3} \mathrm{H}$-thymidine $24 \mathrm{hr}$ after lesion. $B$, A labeled cell from an animal that was pulselabeled $48 \mathrm{hr}$ after lesion. This cell is hypertrophic. $C$, A labeled cell from an animal that was pulse labeled $7 \mathrm{~d}$ after lesion. All cells shown were within $200 \mu \mathrm{m}$ from the borders of the lesion cavity. The lack of clarity of the anti-NG2 reaction product is due to the layer of autoradiographic emulsion. Magnification, $637 \times$.

NG2-positive cells incorporated the label into their nuclei beginning at 1dpl. The NG2-positive cells continued to synthesize DNA for up to $7 \mathrm{~d}$ after lesion (Fig. $4 C$ ).

To quantitate this increase in apparent mitotic activity among the glial cells surrounding the damaged tissue, all silver grainlabeled nuclei within a $200 \mu \mathrm{m}$-wide-annulus surrounding the lesion site were counted and scored for immunohistochemical staining (greater than $90 \%$ of the silver grain-labeled cells fell within this $200 \mu \mathrm{m}$-wide-annulus; see also Fig. 10). Table 1 shows that at $24 \mathrm{hr}$ postlesion, the incidence of silver grainlabeled cells per unit area is approximately 4.5 -fold higher than in normal uninjured tissue. Of those silver grain-labeled cells, approximately $82 \%$ bound the anti-NG2 antibodies. When animals were pulse labeled at $2 \mathrm{dpl}$, the number of silver grainlabeled cells had increased 22-fold above normal tissue. At this time, the NG2-labeled cells comprised $44 \%$ of the silver grainlabeled cells. (Thymidine incorporation into GFAP-positive astrocytes, microglia and monocytes is described below.) At $5 \mathrm{dpl}$, the density of silver grain-labeled cells reached a maximum of approximately 10 silver grain-labeled cells per $40,000 \mu^{2}$ and then declined at $7 \mathrm{dpl}$ to a value that was still ninefold higher than that of normal uninjured tissue. At both 5 and $7 \mathrm{dpl}$, the NG2-positive cells comprised about $25 \%$ of all the silver grainlabeled cells. These data demonstrate that the NG2-positive cells immediately surrounding a puncture lesion initiate DNA synthesis rapidly after injury. Moreover, these cells make up the majority of the cells that synthesize DNA during the first $52 \mathrm{hr}$ after injury.

\section{Injury induced changes in other glial cells}

To compare the injury induced changes among NG2-positive cells with changes among other glial types, serial sections through the damaged area were stained with antibodies that identify microglia (OX42, Perry et al., 1985) and astrocytes (anti-GFAP, Bignami et al., 1972). Additional serial sections were stained with monoclonal antibody ED1 (Dijkstra et al., 1985) in order to monitor the infiltration of monocytes and macrophages from the circulation.

As shown in Figure 5, microglia rapidly became activated by injury and increased in number in the damaged tissue. In normal tissue, ramified microglia were uniformly scattered throughout the cerebellar cortex (Fig. 5A). At $24 \mathrm{hr}$ postlesion, ameboid microglia appeared at the borders of the lesion (Fig. $5 B$ ). Microglia located greater than $100 \mu \mathrm{m}$ from the lesion site had a ramified morphology suggesting that they were unaffected by the lesion. The incidence of the ameboid, activated microglia increased so that by $7 \mathrm{dpl}$, OX42-positive microglia formed a dense network, surrounding and, in some cases, partially filling, the lesion site (Fig. 5C). Beginning at about $15 \mathrm{dpl}$, the number of microglia declined (Fig. $5 D$ ); however, an increased incidence

Table 1. ${ }^{3}$ H-thymidine incorporation after injury

\begin{tabular}{llllll} 
dpl & $\begin{array}{l}\text { Labeled cells/ } \\
40,000 \mu \mathrm{m}^{2}\end{array}$ & $\begin{array}{l}\text { \% NG2 } \\
\text { positive }\end{array}$ & \% Microglia & $\begin{array}{l}\text { \% Monocytes/ } \\
\text { macrophages }\end{array}$ & \% Astrocytes \\
\hline 0 & $0.38 \pm 0.1$ & 70 & ND & ND & 20 \\
1 & $1.73 \pm 0.5$ & $81.9 \pm 7.7$ & $8.1 \pm 3.7$ & ND & $15.6 \pm 6.6$ \\
2 & $8.52 \pm 5.1$ & $43.9 \pm 6.9$ & $35.4 \pm 6.4$ & $20.9 \pm 5.2$ & $11.0 \pm 1.8$ \\
5 & $9.55 \pm 7.5$ & $25.9 \pm 4.4$ & $38.5 \pm 9.3$ & $17.6 \pm 3.9$ & $23.5 \pm 5.7$ \\
7 & $3.46 \pm 2.0$ & $28.1 \pm 6.7$ & $35.8 \pm 12.0$ & $30.9 \pm 15.2$ & $25.4 \pm 10.0$
\end{tabular}

Animals were pulse-labeled with ${ }^{3} \mathrm{H}$-thymidine at the indicated postlesion time and prepared for autoradiography and immunohistochemistry as described in Materials and Methods. Silver grain-labeled cells lying within $200 \mu \mathrm{m}$ of the borders of the lesions were counted and scored for staining with the cell type-specific markers used here. Data shown is the mean \pm SEM of cell counts taken from four serial sections from at least three different levels containing a puncture lesion from two animals for each time point. In this manner, a minimum of 24 sections were counted for each time point. dpl, days postlesion; ND, not determined; $0 \mathrm{dpl}$ indicates a normal animal. 

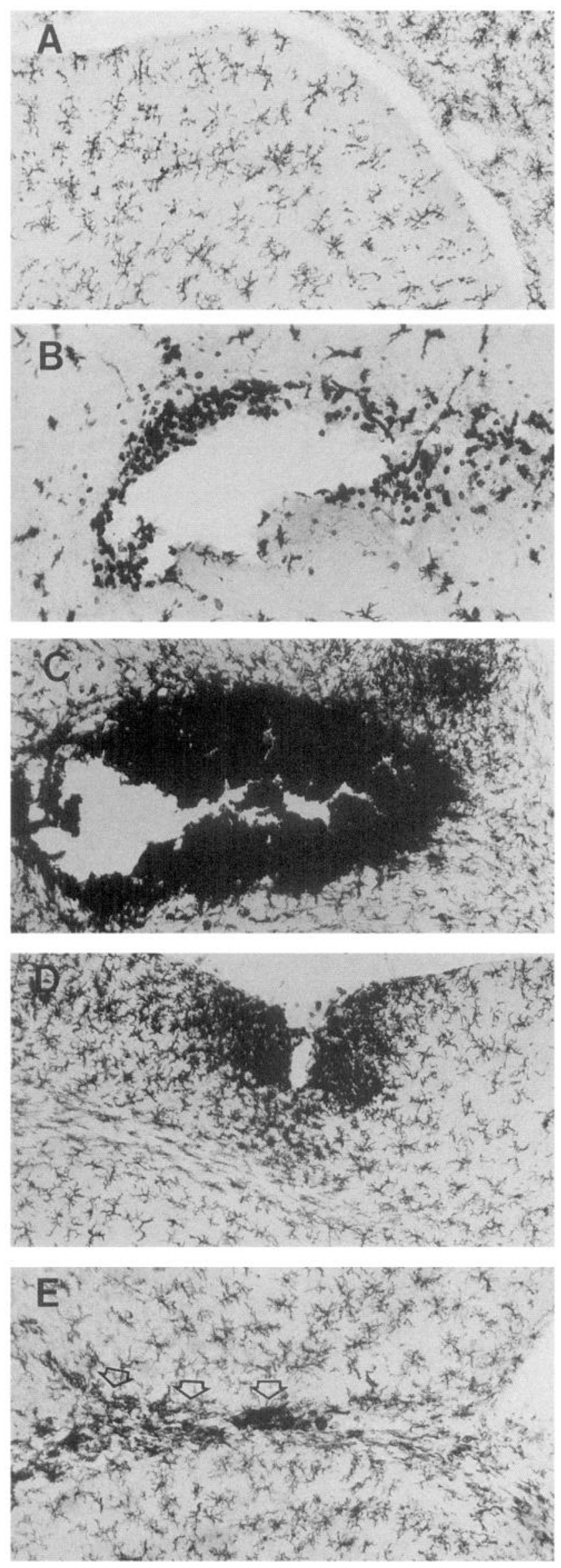

of microglia was apparent at survival times of up to $56 \mathrm{dpl}$ (Fig. $5 E$ ). These increases in the number of microglia are likely due to cell division as microglia comprise $35-40 \%$ of all the cells labeled with silver grains after a pulse of ${ }^{3} \mathrm{H}$-thymidine at survival times greater than $2 \mathrm{dpl}$ (Table 1 ).

Since the increases in the appearance of microglia are temporally and spatially coincident with the increases in the expression of the NG2 PG, double-label immunofluorescence was used to determine whether the same population of cells expressed both the $\mathrm{C} 3 \mathrm{~b}$ receptor that is recognized by the OX42 antibody and the NG2 PG. Figure 6 shows normal and lesioned tissue stained with a rabbit anti-NG2 antiserum and with monoclonal antibody OX42. These two antibodies mark different populations of glial cells in normal tissue (Fig. $6 A, B$ ). At $2 \mathrm{dpl}$, large numbers of round, OX42-positive cells appeared at the lesion border. Intermixed with these cells were irregularly shaped cell bodies that bound the anti-NG2 antibodies heavily (Fig. $6 C, D$ ). By $4 \mathrm{dpl}$, the numbers of NG2-positive and OX42positive cells had increased so that a dense plaque of immunoreactivity developed (Fig. $6 E, F$ ). In general, the OX42 cells had the spherical appearance characteristic of activated microglia whereas anti-NG2 immunoreactivity was associated with a dense meshwork of thin processes. The fluorescence micrographs shown in Figure 6 suggest that the anti-NG2 antibodies and the OX42 antibodies mark two separate and distinct populations of cells that overlap in their distribution after lesion. To examine the distribution of these two cell types further, we analyzed double-labeled tissue prepared at $6 \mathrm{dpl}$ using scanning confocal microscopy. As shown in Figure 7, thin NG2-positive processes appear to ramify closely around the surfaces of the round, OX42-positive cells. These data suggest that, after lesion, NG2-positive processes are distinct from but closely associated with the OX42-positive microglia. However, given the dense deposits of anti-NG2 immunoreactivity that develop after lesion and the phagocytotic functions of activated microglia, it is possible that some of the anti-NG2 staining is associated with microglia.

The puncture lesions employed here damage the blood-brain barrier and monocytes and macrophages, visualized with monoclonal antibody ED1, rapidly infiltrated the wound (Fig. 8). The ED1-positive cells resemble the activated, OX42-positive microglia and increased in number around the lesion site with the same time course as did the microglia although the percentage of monocytes that incorporated ${ }^{3} \mathrm{H}$-thymidine was lower than microglia (Table 1). At longer survival times, the EDI-positive monocytes appeared to have migrated away from the lesion site and assumed a ramified morphology.

The appearance of GFAP immunoreactivity after lesion is shown in Figure 9. At $1 \mathrm{dpl}$, there was a loss of immunoreactivity immediately adjacent to the lesion site, most likely due to direct damage of astrocytes. As reported by others (Cavanagh, 1970;

\footnotetext{
Figure 5. Distribution of OX42-immunolabeled microglia in normal and lesioned cerebellum. $A, \mathrm{OX} 42$-positive microglia in the normal cerebellar cortex. B, Twenty-four hours postlesion. Many round, immunopositive cells appear in the area immediately surrounding the lesion site. $C$, Seven days postlesion. A dense plaque of immunoreactivity surrounds the lesion site. $D$, Fifteen days postlesion. OX42-positive microglia remain clustered around the lesion site at a lower density than at $7 \mathrm{~d}$ postlesion. $E$, Fifty-six days postlesion. Ameboid and ramified microglia, both of which are immunopositive, remain clustered at the lesion site (open arrowheads). Magnification, $96 \times$.
} 

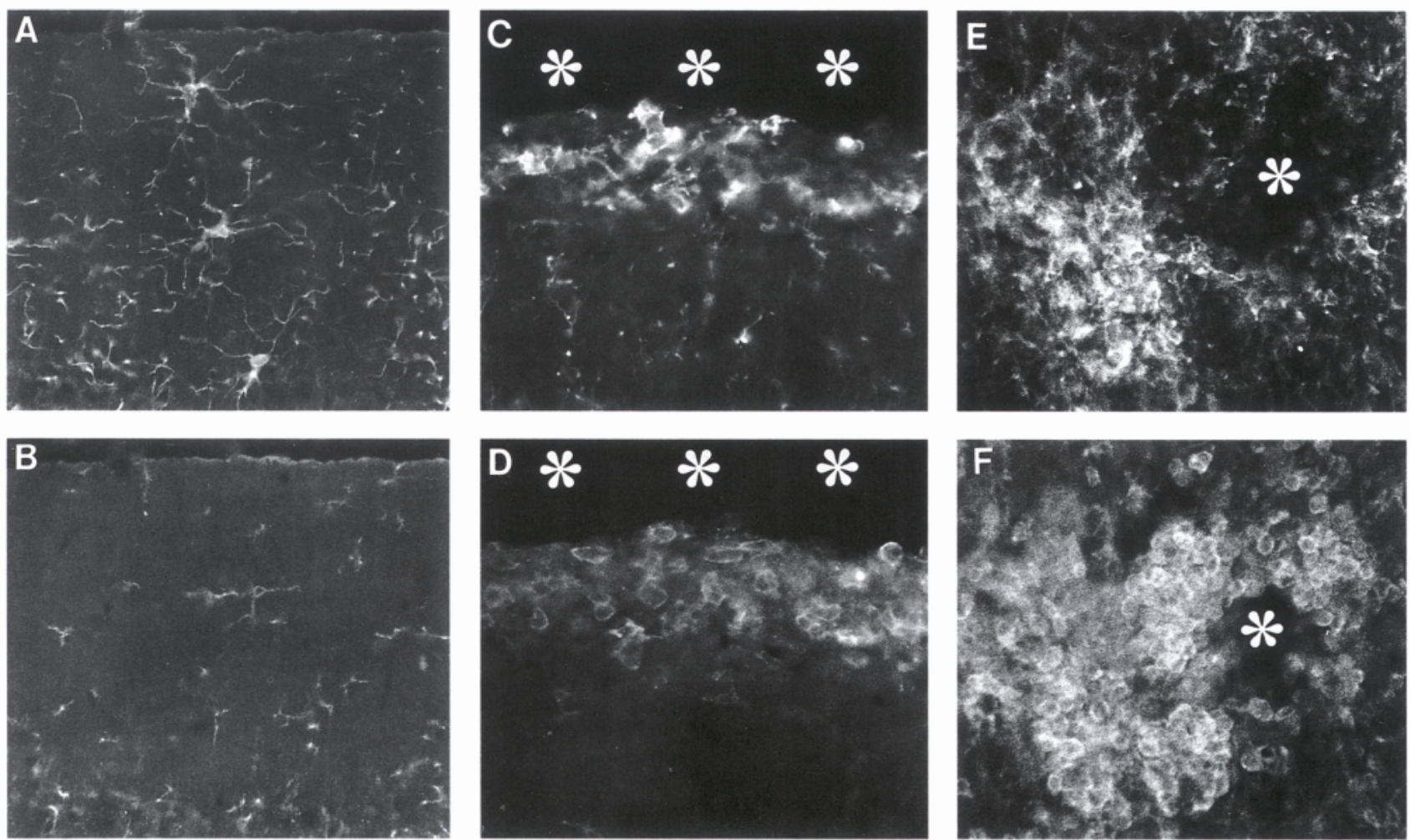

Figure 6. Double-label fluorescent localization of the NG2 PG and the OX42 antigen in normal and lesioned cerebellum. $A$, NG2 immunoreactivity, normal cerebellum. $B$, OX42 immunoreactivity in the same section. The NG2 PG and the OX42 antigen mark different and nonoverlapping populations of glial cells. $C$, NG2 immunoreactivity in a section from an animal killed $48 \mathrm{hr}$ postlesion. Round and ovoid cells appear at the borders of the lesion. $D$, OX42 immunostain of the same section. The ameboid microglial that bind the OX 42 antibodies are distinct from the NG2-positive cells. In $C$ and $D$, the lesion cavity is marked with asterisks. $E$, Four days postlesion, NG2 immunostain. Labeled processes ramify heavily around the lesion site which is marked with an asterisk. $F, \mathrm{OX} 42$ immunostain of the same section. Large numbers of round, NG2-negative cells surround and partially fill the lesion site. NG2 immunoreactivity was visualized with FITC; OX42 immunoreactivity with Texas red as described in Materials and Methods. Magnification, 220×.

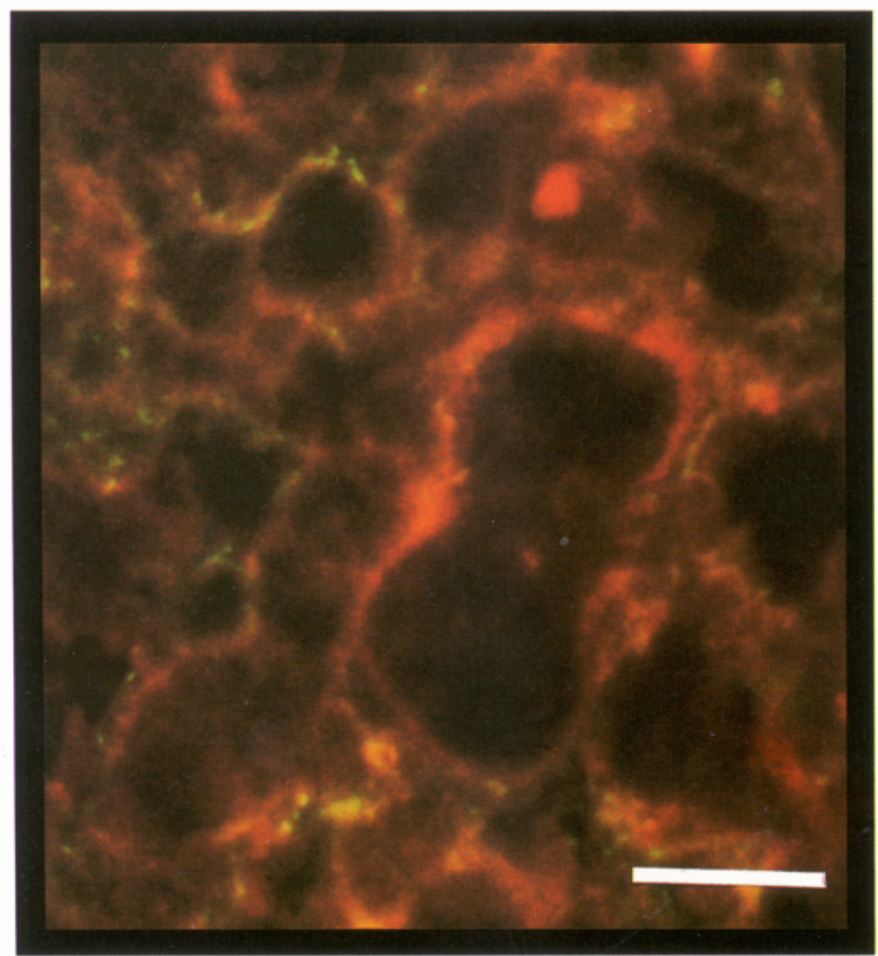

Latov et al., 1979; Mathewson and Berry, 1985; Miyake et al., 1988, 1992; Takamiya et al., 1988; Topp et al., 1989), enlarged GFAP-positive processes first appeared at $2 \mathrm{dpl}$ and a welldeveloped glial scar was seen by $7 \mathrm{dpl}$. This glial scar becomes a permanent feature of the damaged cerebellum and is maintained for up to $56 \mathrm{dpl}$. The data in Table 1 show that few GFAP-positive astrocytes had initiated DNA synthesis 24-48 $\mathrm{hr}$ after lesion and that the proportion of silver grain-labeled cells that express GFAP-like immunoreactivity increased at 5 and $7 \mathrm{dpl}$ when they constituted approximately $25 \%$ of all silver grain-labeled cells. This is in contrast to the NG2-positive glial cells which initiate DNA synthesis soon after injury.

\section{The fate of NG2-positive cells after injury}

The transient increase in the incidence of NG2-positive cells after injury raises the question of the fate of these cells. To

\section{$\leftarrow$}

Figure 7. Simultaneous localization of OX42 and NG2 antigens in tissue prepared $6 \mathrm{~d}$ after lesion. This photomicrograph was prepared by scanning confocal microscopy and is a projection of three scans through the section taken at $1 \mu \mathrm{m}$ intervals. Red represents OX 42 staining, which was visualized with a Texas red-conjugated goat anti-mouse antibody, and the greenish-yellow represents anti-NG2 immunoreactivity visualized with a fluorescein-conjugated goat anti-rabbit antibody. Note that the NG2-positive fibers ramify closely around the surfaces of the OX42positive ameboid microglia. Scale bar, $10 \mu \mathrm{m}$. 

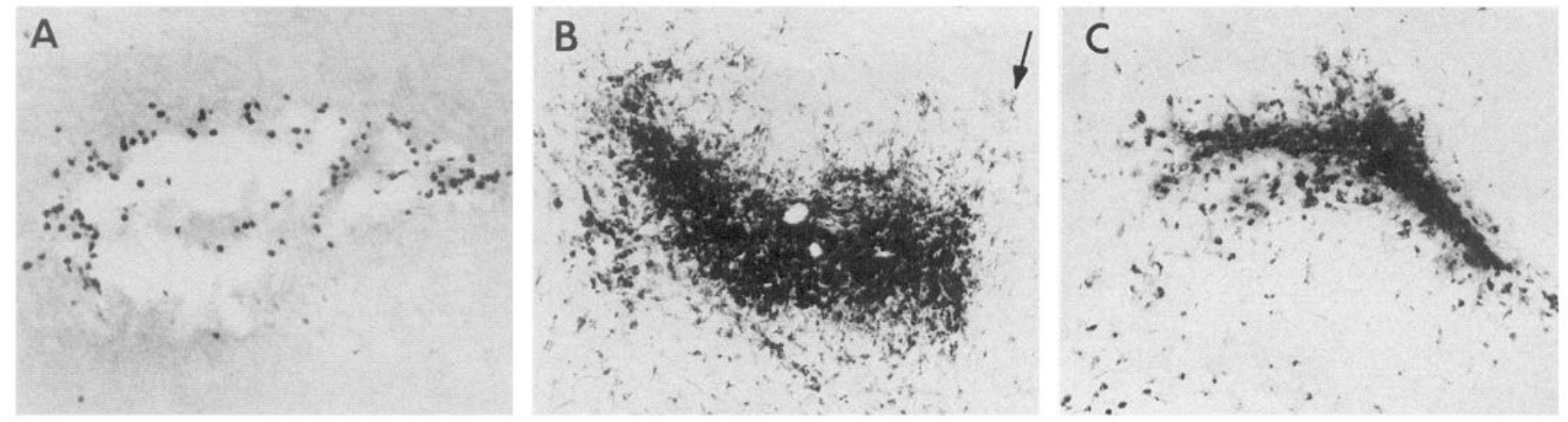

Figure 8. Localization of EDI-positive monocytes and macrophages in lesioned cerebellar tissue. $A$, Twenty-four hours postlesion. Only a few, scattered monocytes have invaded the wound. $B$, Seven days postlesion. Monocytes and macrophages form a dense plaque surrounding the lesion site. The arrow points to a cell that has a ramified morphology. $C$, Thirty days postlesion. Monocytes and macrophages persist at the wound and are scattered throughout the adjacent, noninjured tissue. In normal cerebellum, EDl-positive monocytes and macrophages are only found within the meninges and blood vessels (data not shown). Magnification, $97 \times$.

determine whether these cells and other glial cell types are capable of continued DNA synthesis, lesioned animals were injected with ${ }^{3} \mathrm{H}$-thymidine at 1 and $2 \mathrm{dpl}$ and allowed to survive for $30 \mathrm{~d}$ before the animals were killed and the tissue prepared for immunocytochemistry and autoradiography. The dark-field photomicrographs shown in Figure 10 demonstrate that the density of silver grain-labeled cells surrounding the lesion was increased after a $30 \mathrm{~d}$ survival when compared to the pulse only experiments described above. In addition to a 5-15-fold increase in the number of labeled cells per $40,000 \mu \mathrm{m}^{2}$ of tissue
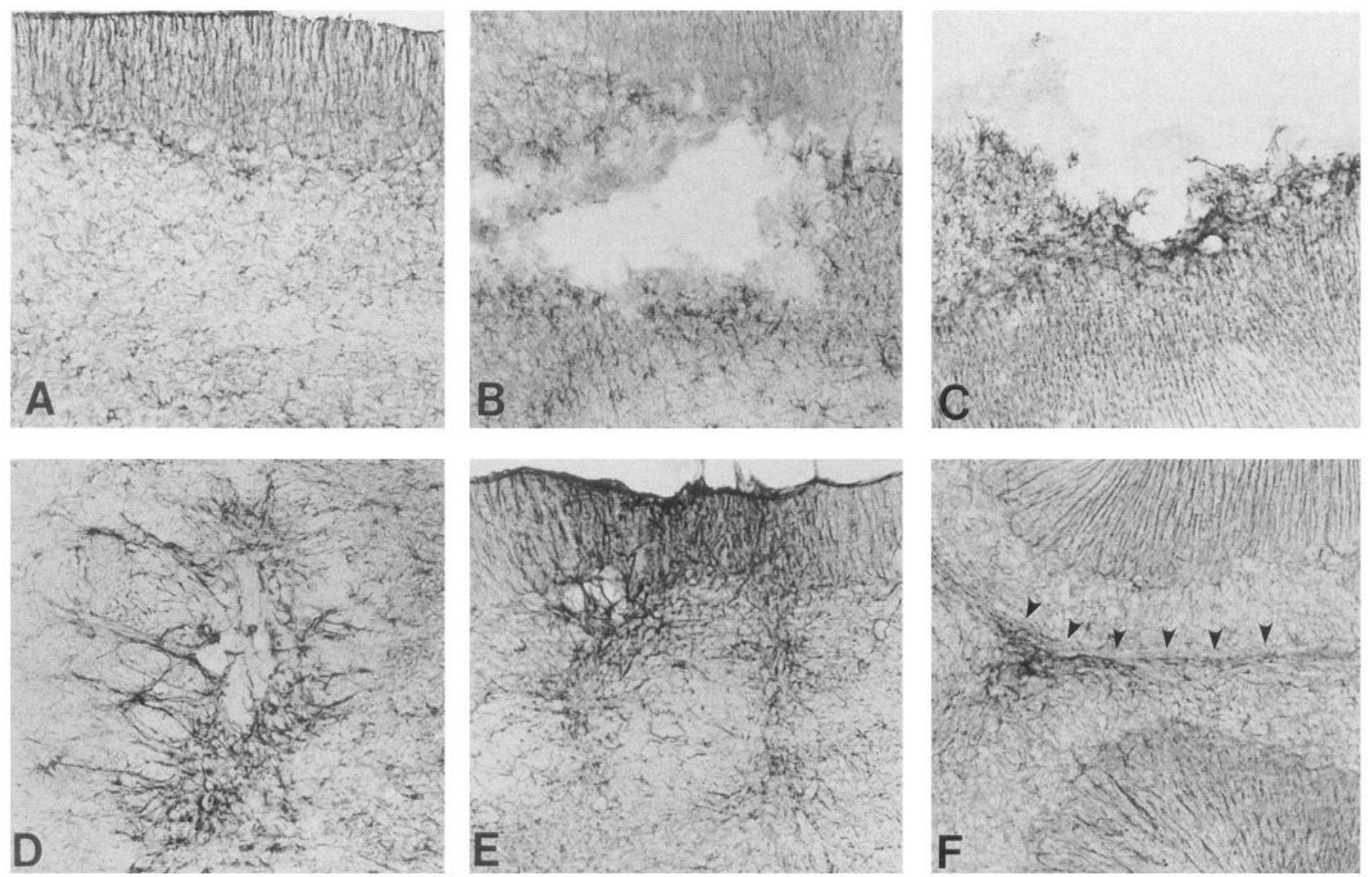

Figure 9. GFAP immunoreactivity in normal and lesioned cerebellum. $A$, Normal cerebellum. GFAP immunoreactivity is found within the Bergmann glial fibers and astrocytes within the internal granule layer. $B$, Twenty-four hours postlesion. There is a loss of GFAP immunoreactivity immediately adjacent to the needle track. $C$, Forty-eight hours postlesion. Astrocytes immediately adjacent to the needle track are densely-stained. $D$, Seven days postlesion. Enlarged GFAP-positive fibers surround the lesion site and form a glial scar. $E$, Thirty days postlesion. GFAP-positive scars mark two lesion sites. $F$, Fifty-six days postlesion. Hypertrophic astrocytes remain at the lesion site (arrowheads). Elsewhere in the section, astrocytes appear normal. Magnification, $100 \times$. 

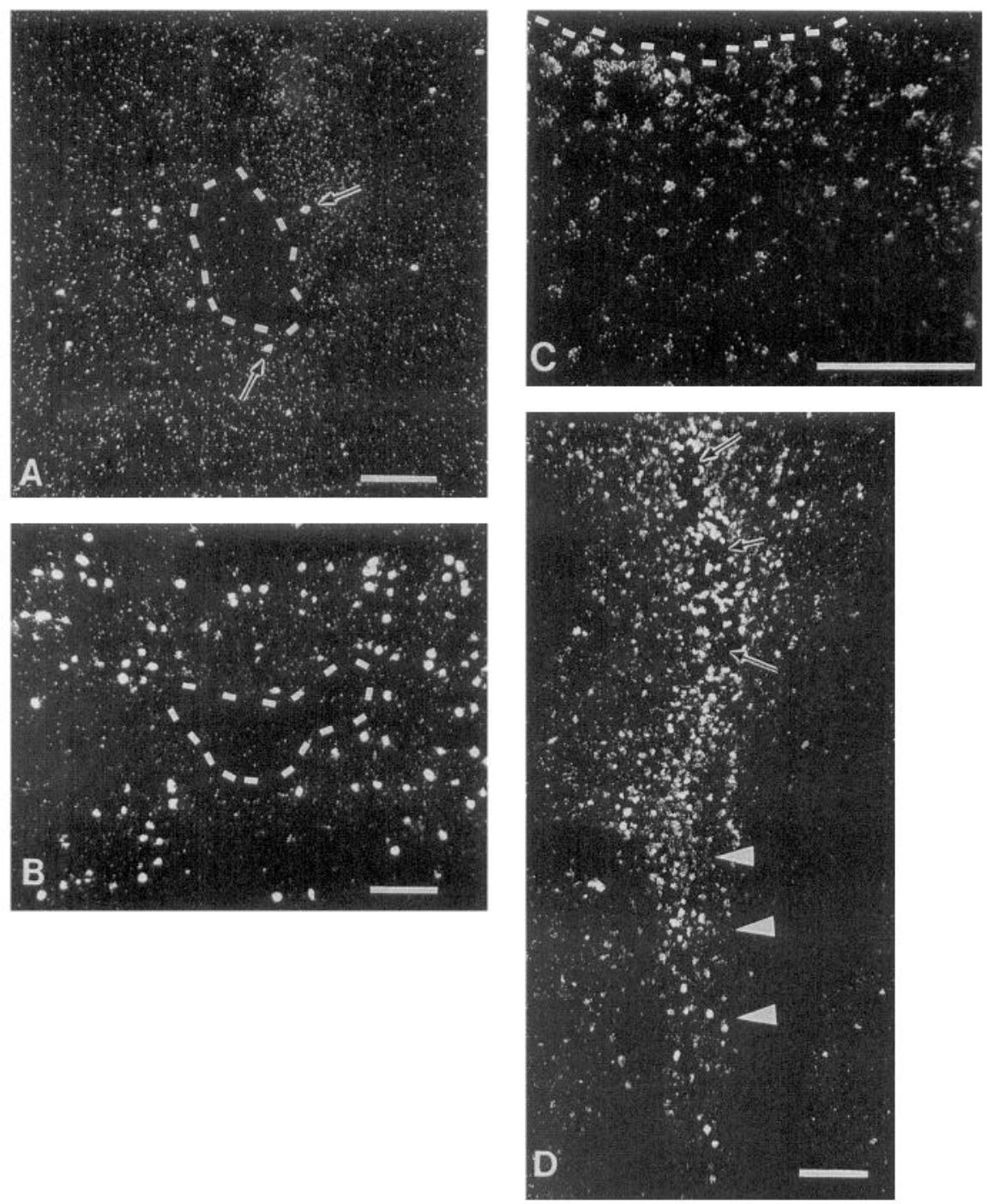

Figure 10. The distribution of thymidine-labeled cells in animals that were pulsed with ${ }^{3} \mathrm{H}$-thymidine at 1 and $2 \mathrm{~d}$ postlesion and animals that were allowed to survive for $30 \mathrm{~d}$ after ${ }^{3} \mathrm{H}$-thymidine injection at 1 and $2 \mathrm{~d}$ postlesion (dark-field photomicrographs of cresyl violet-stained sections). $A$, Pulse label at $24 \mathrm{hr}$ postlesion. Labeled cells lie close to the lesion site which is outlined by the dotted lines. $B$, Pulse label at $48 \mathrm{hr}$ postlesion. The number of labeled cells is increased relative to $A$, yet the cells remain clustered around the lesion site which is indicated by the dotted line. $C$, Pulse-chase label at $24 \mathrm{hr}$ postlesion. The numbers of labeled cells has increased relative to $A$ and they are more widely distributed. The border of the lesion lies at the top of the figure and is marked by a broken line. $D$, Pulsechase label at $48 \mathrm{hr}$ postlesion. Labeled cells have migrated within the white matter. The arrows point to the lesion site and the arrowheads point to thymidine-labeled cells within the white matter. Scale bars, $100 \mu \mathrm{m}$. adjacent to the lesion site (compare Table 1 and Table 2), many silver grain-labeled cells were observed at distances greater than $200 \mu \mathrm{m}$ from the lesion site (Fig. 10D). In animals labeled 24 $\mathrm{hr}$ after lesioning and allowed to survive for 30 additional days, the density of silver grain-labeled cells lying between $200-400$ $\mu \mathrm{m}$ from the lesion site was $5.17 \pm 1.7$ cells $/ 40,000 \mu \mathrm{m}^{2}$. In animals that were labeled at $2 \mathrm{dpl}$, this number increased to $15.1 \pm 6.1$ cells $/ 40,000 \mu \mathrm{m}^{2}$. (In normal cerebellar tissue subjected to the same $30 \mathrm{~d}$ postinjection survival paradigm, there were $2.46 \pm 1.6$ silver grain-labeled cells $/ 40,000 \mu \mathrm{m}^{2}$.) These distally located cells tended to lie in the white matter but were also found within the cellular layers of the cerebellar cortex. Thus, it appears that some of the glial cells that initiate DNA synthesis within $48 \mathrm{hr}$ of lesion or their progeny can migrate away from the lesion site.

To quantitate the number of silver grain-labeled cells in this pulse-chase paradigm, all the silver grain-labeled cells lying within $200 \mu \mathrm{m}$ of the borders of the lesions were counted and scored for the expression of the cell type-specific markers used here. As shown in Table 2, not only was there an increase in the density of labeled cells lying close to the lesion relative to the pulse only cases, but the relative proportions of the cell types that were labeled with silver grains differed considerably from the pulse only cases. For example, whereas the NG2-labeled cells comprised the largest group of cells that incorporate ${ }^{3} \mathrm{H}$ thymidine at 1 and $2 \mathrm{dpl}$, only $16 \%$ of the labeled cells in the pulse-chase experiments expressed the NG2 PG. Similarly, GFAP-containing astrocytes were a small component of the silver grain-labeled cells after a pulse but, together with microglia, comprise the largest component of the cells that are labeled after a $30 \mathrm{~d}$ chase. This suggests that the astrocytes and microglia that synthesize DNA soon after injury can continue

\begin{tabular}{|c|c|c|c|c|c|}
\hline dpl & $\begin{array}{l}\text { Labeled } \\
\text { cells } / 40,000 \\
\mu \mathrm{m}^{2}\end{array}$ & $\begin{array}{l}\% \text { NG2 } \\
\text { positive }\end{array}$ & $\%$ Microglia & $\begin{array}{l}\% \text { Mono- } \\
\text { cytes/ } \\
\text { macrophages }\end{array}$ & $\begin{array}{l}\% \\
\text { Astrocytes }\end{array}$ \\
\hline 1 & $28.6 \pm 6.9$ & $16.8 \pm 2.5$ & $28.5 \pm 9.7$ & $13.6 \pm 6$ & $30.1 \pm 3.7$ \\
\hline 2 & $43.9 \pm 9.8$ & $16.1 \pm 0.6$ & $30.4 \pm 1.6$ & $11.3 \pm 1.4$ & $24.9 \pm 4.7$ \\
\hline
\end{tabular}

Animals were injected with ${ }^{3} \mathrm{H}$-thymidine at the indicated postlesion times and allowed to survive for 30 additional days before death. The tissue was prepared for autoradiography and immunohistochemistry as described in Materials and Methods. Silver grain-labeled cells lying within $200 \mu \mathrm{m}$ of the borders of the lesions were counted and scored for staining with the cell type-specific markers as described in Table 1. dpl, days postlesion. 

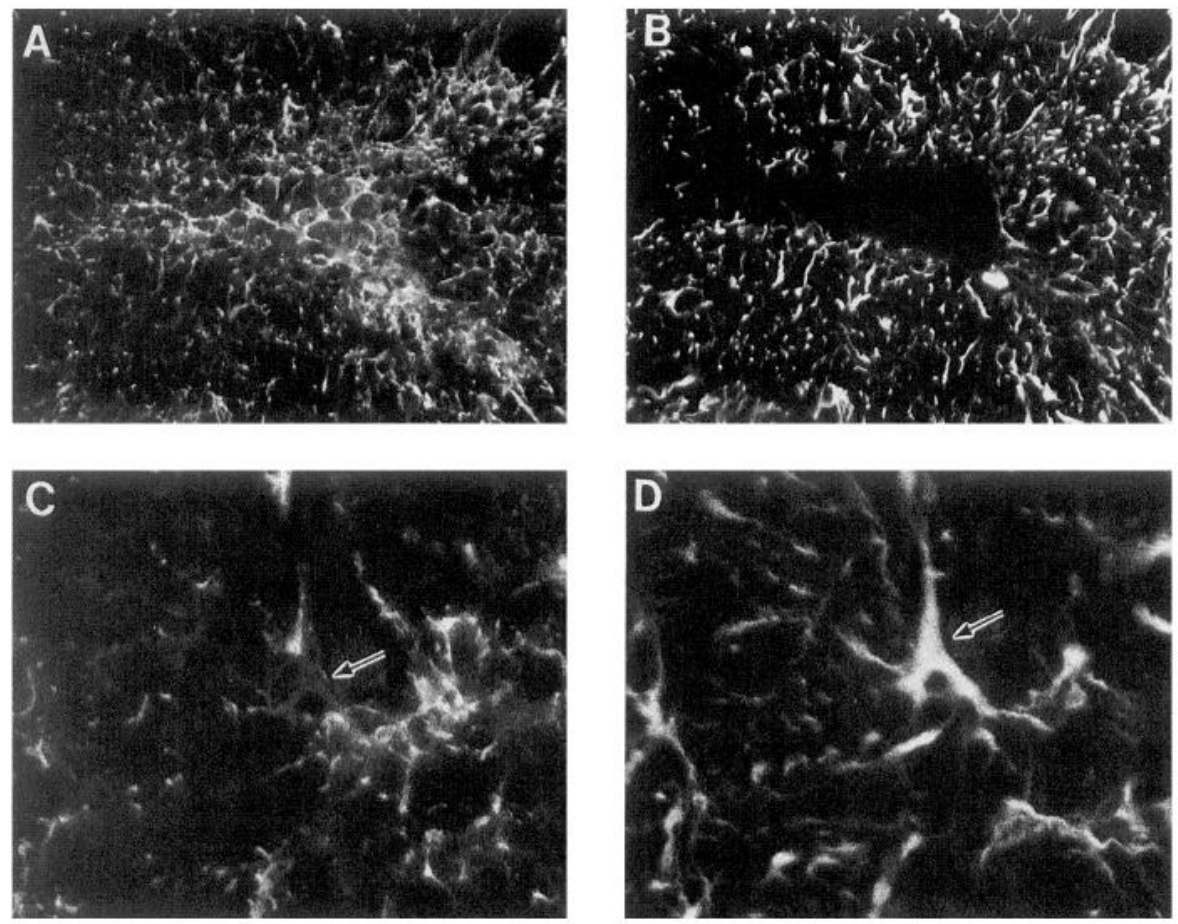

Figure 11. Simultaneous localization of the NG2 PG and GFAP antigens in lesioned cerebellum. $A$ and $B$, Six days postlesion. In $A$, NG2-positive cells and fibers surround and fill the lesion cavity. In $B$, enlarged, GFAP-positive fibers form a scar around the lesion site. $C$ and $D$, Six days postlesion. The NG2positive cells and fibers shown in $C$ are distinct from the GFAP-positive cells and fibers shown in $D$. The arrows points to a large, reactive astrocyte that is GFAP positive and NG2 negative. $E$ and $F$, Eight days postlesion. Although the NG2-positive cell bodies and fibers shown in $E$ lie close to the GFAP-positive fibers shown in $F$, they are immunologically distinct. Magnification: $A$ and $B, 178 \times ; C$ and $D, 620 \times ; E$ and $F, 786 \times$
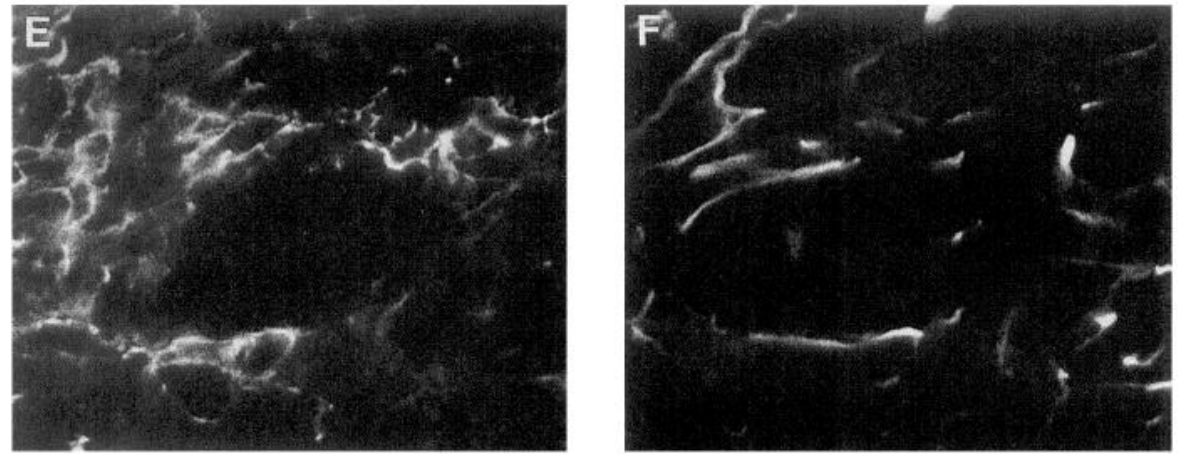

to divide after injury. Newly generated NG2-positive cells, on the other hand, may migrate away from the lesion.

An alternative explanation for the relatively low labeling index among NG2-positive cells and the higher index among GFAP-positive astrocytes in the pulse-chase experiments would be that some of the NG2-expressing cells develop into GFAPpositive astrocytes, as they can do in vitro (Levine et al., 1993). To address this possibility, cryostat section of lesioned tissue were double labeled with a rabbit antiserum against the NG2 core protein and a monoclonal antibody against GFAP. Figure 11 shows double-stained tissue prepared 6 and $8 \mathrm{~d}$ after lesion, a time at which the glial scar is forming and the increased expression of the NG2 PG is maximal. GFAP-positive fibers form a dense meshwork at the edges of the lesion cavity. In the cases shown, increased levels of NG2 immunoreactivity were found both surrounding the lesion and within the lesion cavity. The cavities were filled with EDI-positive monocytes and macrophages (data not shown). Although there was considerable spatial overlap in the distribution of both GFAP and the NG2 PG, most individual cells and processes expressed either GFAP antigens or the NG2 PG but not both antigens simultaneously
(Fig. $11 C-F$ ). When lesioned tissue was examined using scanning confocal microscopy, NG2-positive cells and processes were seen closely opposed to and along the GFAP-positive cells and processes (fig. $11 A, B$ ). Only rarely was an individual process apparently stained with both antibodies (Fig. 12B). Such processes often had the fluorescent staining for NG2 and GFAP antigens segregated into different spatial domains, making it difficult to determine whether the differentially stained domains were in fact physically contiguous. Although this data suggests that NG2-positive glial progenitor cells do not differentiate into astrocytes after injury, this possibility cannot be completely ruled out given the limitations of the double-label fluorescence techniques.

\section{Discussion}

Injury to the mature CNS leads to the formation of a permanent scar at the site of damage (Berry et al., 1983; Reier et al., 1983). Hypertrophic astrocytes and their processes are the major constituents of this scar although scar tissue also contains meningeal and other cell types including macrophages, microglia, and fibroblasts as well as extracellular matrix components (Liesi et 
al., 1984; Egan and Vijayan, 1991). The data presented here demonstrate that a class of adult glial cells which expresses the NG2 PG participates transiently in scar formation after injury. These cells synthesize DNA soon after injury, increase in number and bind the anti-NG2 antibodies more heavily than do cells in normal tissue. The transient upregulation of the expression of immunodetectable levels of the NG2 PG is accompanied by increases in the levels of mRNAs encoding NG2. Although these cells become hypertrophic in a manner similar to that described for reactive astrocytes (Reier et al., 1983; Mathewson and Berry, 1985; Schiffer et al., 1986; Mikaye et al., 1988; Takamiya et al., 1988; Topp et al., 1989), the changes in cell size and NG2 expression are transient and by 2 months after injury, the distribution of the NG2 PG around the damaged site is only barely distinguishable from that of normal tissue. These observations demonstrate that the NG2-positive cells of adult animals are a reactive cell type.

The anti-NG2 antibodies used here mark an unusual and poorly understood glial cell type (Levine and Card, 1987; Levine et al., 1993). In vivo, NG2-positive cells have ultrastructural features that are associated with smooth protoplasmic astrocytes (Peters et al., 1976), $\beta$-astrocytes (Reyners et al.,1982), and a third glial type (Vaughn and Peters, 1968). In dissociated cell cultures prepared from either neonatal or adult animals (Levine and Stallcup, 1987; Stallcup and Beasley, 1987; Levine et al., 1993), the NG2 PG is expressed on a population of cells that display the phenotypic plasticity that is characteristic of $\mathrm{O} 2 \mathrm{~A}^{\text {nconatal }}$ and $\mathrm{O} 2 \mathrm{~A}^{\text {adult }}$ progenitor cells. Although a small number of flat cells in these cultures also express the NG2 PG, most of the NG2-positive cells have either a bipolar or multipolar morphology. These process-bearing cells bind antibodies against the A2B5 antigen and against GD3 ganglioside, two additional markers for O2A progenitor cells. The NG2-positive cells do not bind the OX42 antibodies, a marker for microglia, nor do they bind Griffonia simplicifolia $\mathrm{B}_{4}$ isolectin, an additional histochemical marker for microglia (Streit et al., 1988; J. M. Levine, unpublished observations). Varying proportions of the NG2positive cells of either neonatal or adult cerebellum express the 04 antigen, a surface marker of oligodendrocyte precursor cells (Goldman, 1992) and O2A adult progenitor cells (Wolswijk and Noble, 1989). Although it is possible that some of the cells that express the NG2 PG in culture may be derived from cells other than those that express NG2 in situ, the evidence summarized above strongly suggests that the NG2-expressing cells are indeed $\mathrm{O} 2 \mathrm{~A}$ progenitor cells. The data presented here demonstrate that one function of these cells is to participate in the reactions to brain injury.

One feature of the response of the NG2-positive cells to injury is the rapid initiation of DNA synthesis. By $24 \mathrm{hr}$ after injury, NG2-positive cells begin to synthesis DNA and continue to do so for at least 1 week. Based on our counts of silver grainlabeled cells, we estimate that at $24 \mathrm{hr}$ after injury, every 100,000 $\mu \mathrm{m}^{2}$ of reactive tissue surrounding a lesion would contain approximately four or five glial cells in $\mathrm{S}$ phase, three of which express the NG2 PG. In the normal cerebellum, an area of $100,000 \mu \mathrm{m}^{2}$ would contain approximately 14 NG2-positive cells (Levine et al., 1993). Thus, about 20\% of the NG2-positive cells lying within $200 \mu \mathrm{m}$ of a puncture lesion are in $\mathrm{S}$ phase during a $4 \mathrm{hr}$ window taken $24 \mathrm{hr}$ after injury. This is in contrast to normal cerebellar tissue in which only $0.14-0.28 \%$ of the NG2positive cells incorporate ${ }^{3} \mathrm{H}$-thymidine into their nuclei after pulse labeling with ${ }^{3} \mathrm{H}$-thymidine (Levine et al., 1993). The

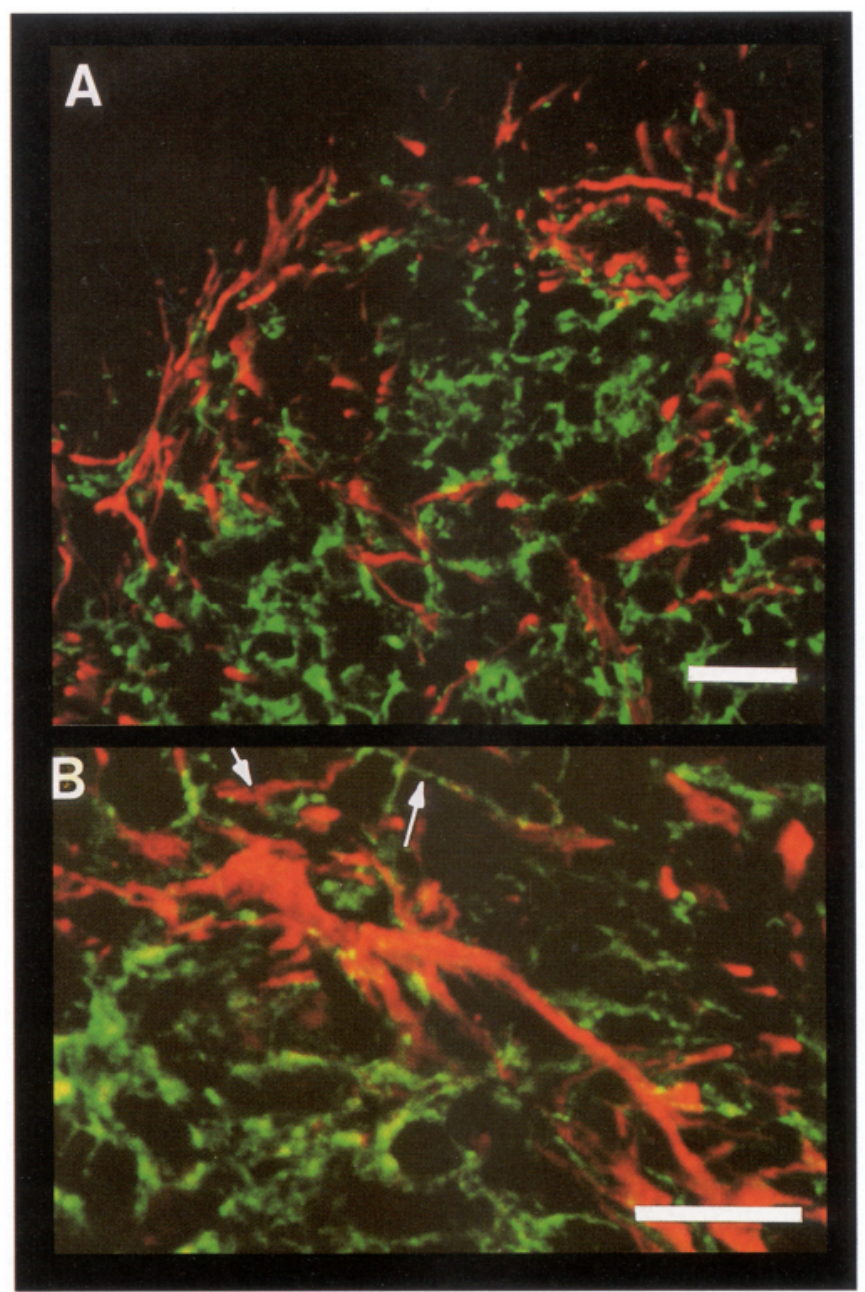

Figure 12. Localization of GFAP and NG2 antigens in tissue prepared $6 \mathrm{~d}$ after lesion by scanning confocal microscopy. Red indicates the GFAP antigens visualized with a Texas red-conjugated anti-mouse antibody, and the green, NG2 antigens visualized with a fluorescein-conjugated anti-rabbit antibody. Yellow indicates areas where the two fluorochromes overlap. A, An low-power view of a small lesion. GFAPpositive fibers form a scar surrounding the lesion whereas NG2-positive fibers are found both within the lesion cavity and surrounding the lesion. $B$, Higher-power view of a hypertrophic astrocyte. Small, NG2-positive fibers ramify close to this astrocyte. The arrow points to a small process that may express both the NG2 PG and GFAP-antigens in separate physical domains. Scale bars, $25 \mu \mathrm{m}$.

number of NG2-positive cells in S phase increases at 2 and 5 $\mathrm{dpl}$ and declines to approximately $1 \mathrm{cell} / 40,000 \mu \mathrm{m}^{2}$ at $7 \mathrm{dpl}$.

The other cell types analyzed here, monocytes and macrophages, microglia, and astrocytes also respond to injury by initiating DNA synthesis. After cerebellar lesion, astrocytes become maximally labeled following a pulse of ${ }^{3} \mathrm{H}$-thymidine at $5 \mathrm{dpl}$, a delay consistent with previous studies (Cavanagh, 1970; Latov et al., 1979; Takamiya et al., 1987; Topp et al., 1989; Miyake et al., 1992). OX42-positive microglia became labeled in significant numbers at $2 \mathrm{dpl}$ and maintained a high rate of DNA synthesis throughout the first week after lesion. Between 1 and 2 EDl-positive monocytes and macrophages per $40,000 \mu \mathrm{m}^{2}$ became labeled with silver grains following pulses of ${ }^{3} \mathrm{H}$-thymidine at $2-7 \mathrm{dpl}$. This relatively low level of thymidine incorporation suggests that part of the increase in the 
number of ED1-positive cells within injured tissue may be due to either the continued infiltration of cells from the circulation or to the expression of the EDI antigen by activated microglia (Milligan et al., 1991).

The transient increases in number of $\mathrm{NG2}$-positive, $\mathrm{O} 2 \mathrm{~A}^{\text {adult }}$ progenitor cells after injury raises two questions; what mitogens are available to glial cells surrounding the lesion sites and what is the fate of the newly generated cells. Platelet-derived growth factor AA homodimers (PDGF-AA) and basic $\mathrm{FGF}(\mathrm{bFGF})$ are well-characterized mitogens for $\mathrm{O} 2 \mathrm{~A}^{\text {nconatal }}$ progenitor cells (Noble et al., 1988; Richardson et al., 1988; McKinnon ct al., 1990) as is neurotrophin-3 (NT3, Barres et al., 1993). The effects of these defined growth factors on $\mathrm{O} 2 \mathrm{~A}^{\text {adult }}$ progenitor cells is controversial. Wolswijk and colleagues (Wolswijk et al., 1991) have reported that PDGF-AA can stimulate BrdU incorporation into $\mathrm{O} 2 \mathrm{~A}^{\text {adult }}$ progenitor cells isolated from normal optic nerve albeit at a reduced rate compared to the effects of PDGF-AA on $\mathrm{O}_{2} \mathrm{~A}^{\text {nconatal }}$ progenitor cells. However, when cells of the $\mathrm{O} 2 \mathrm{~A}$ lineage, including 04-positive, galactocerebroside-negative cells that correspond immunologically to $\mathrm{O} 2 \mathrm{~A}^{\text {adult }}$ progenitor cells (Wolswijk and Noble, 1989) were isolated from virally demyelinated spinal cord, PDGF did not increase ${ }^{3} \mathrm{H}$-thymidine incorporation above basal levels (Armstrong et al., 1990). These differences may reflect a regional heterogeneity among $\mathrm{O} 2 \mathrm{~A}$ progenitor cells (Levine et al., 1993) or they could be due to prior exposure of the cells to mitogens in vivo in the case of the demyclinating lesions. Regardless, since the puncture lesions used here do extensive damage to the vasculature, as evidenced by the infiltration of monocytes and macrophages, it is reasonable to assume that the NG2-positive cells surrounding the lesions are exposed to increased levels of PDGF. Levels of bFGF are also increased at $7 \mathrm{~d}$ after lesioning the cortex (Finkelstein et al., 1988) and may contribute to the mitogenic stimulation of the cells. Although NT3 has been shown to stimulate BrdU incorporation into O2A $\mathrm{A}^{\text {nconatal }}$ progenitor cells (Barres et al., 1993), it is doubtful that NT3 contributes to this mitogenic activation since levels of NT3 encoding mRNAs decrease after injury (Ip et al., 1993).

Several recent studies emphasize the complex cell-cell interactions that may occur after injury. Injury upregulates the expression of two polypeptide mitogens for microglia (Giulian et al., 1991). The production of these mitogens is maximal at 2 $\mathrm{dpl}$, consistent with the time course of the increases in ${ }^{3} \mathrm{H}$ thymidine labeling of microglia reported here. Microglia and the macrophages that invade the wounds are capable of secreting interleukin- 1 that can stimulate astrocyte proliferation (Giulian and Lachmann, 1985) and vascularization of the damaged tissue (Giulian et al., 1988). Curiously, the expression of transforming growth factor- $\beta 1$, which can inhibit astrocyte proliferation in response to bFGF and epidermal growth factor, is also increased within macrophages and microglia after injury (Lindholm et al., 1992). These studies suggest a major role for macrophages and microglia in controlling the astrocytic response to injury. Whether macrophages and microglia contribute to the regulation of the reactive responses of the NG2-positive cells, as suggested by the close physical association of these cell types within injured tissue, is a subject for future research.

In several previous studies of the astroglial reaction to experimentally induced brain injury, the inferred rate of cell division among GFAP-expressing astrocytes was inadequate to fully explain the increased numbers of astrocytes that appear after injury (Miyake et al., 1988, 1992). This led to the suggestion that injury leads to the expression of GFAP by cells that had undetectable levels of GFAP prior to injury. The transient nature of the increase in the number of NG2-positive, O2A aduit progenitor cells after injury would be explained if some of these cells developed GFAP immunoreactivity as they can do in dissociated culture (Levine et al., 1993). This hypothesis seemed particularly attractive since injury leads to increased levels of mRNA encoding ciliary neurotrophic factor (CNTF, Ip et al., 1993), a factor that transiently induces GFAP expression in embryonic and O2A $\mathrm{A}^{\text {nconatal }}$ progenitor cells (Hughes et al., 1988). Morcover, meningcal cells and endothclial cells, which producc an extracellular matrix that can cooperate with CNTF to stabilize GFAP expression in O2A $\mathrm{A}^{\text {nconatal }}$ progenitor cells (Lillien et al., 1990), are found within the lesioned tissue (Berry et al., 1983). It was therefore disappointing that there was little if any detectable GFAP immunoreactivity within the NG2-positive cells after injury. While the simplest interpretation of these findings is that the NG2-positive, $\mathrm{O} 2 \mathrm{~A}^{\text {adul }}$ progenitor cells do not become astrocytes after injury, it should be emphasized that the complex geometry of the lesioned tissue may obscure such double-labeled cells, if they exist. In addition, if the transition from a reactive progenitor cell that is GFAP-negative to a GFAPpositive astrocyte were either rapid or occurred at low frequency, it would have been difficult to identify intermediate cell types expressing both the NG2 PG and GFAP-type intermediate filaments with the fluorescent techniques used here. Therefore, the question of whether $\mathrm{O} 2 \mathrm{~A}^{\text {adult }}$ progenitor cells can develop into astrocytes after injury remains open.

The data presented here suggest two possible fates for NG2positive, $\mathrm{O} 2 \mathrm{~A}^{\text {adult }}$ progenitor cells after injury. Between 10-15 $\mathrm{dpl}$, when the number of NG2-labeled cells surrounding the lesion declines, many of the NG2-positive cells have swollen cell bodies and short processes. Densely stained, beaded profiles are also abundant at these survival times. These profiles could represent cells undergoing cell death since similar appearing cells were seen at $24 \mathrm{hr}$ postlesion when cells would be dying due to direct physical damage. The idea that glial cells and their precursors undergo naturally occurring cell death is a new one (Barres et al., 1992), and it would not be surprising if glial cell death also occurred during the tissue remodeling and healing that takes place after injury.

The autoradiographic studies suggest another possible fate for these cells after injury. When injured animals were pulsed with ${ }^{3} \mathrm{H}$-thymidine and killed $2-4 \mathrm{hr}$ later, almost all the thymidine incorporating cells were found within $200 \mu \mathrm{m}$ of the borders of the lesion. When the animals were allowed to survive for 30 additional days after administering the ${ }^{3} \mathrm{H}$-thymidine, not only were the numbers of cells that had incorporated thymidine increased, but they were more widely distributed. Thus, glial cells continue to divide after injury and somc of the daughter cells migrate away from the lesion site. This migration appeared to be preferentially but not exclusively within the white matter.

In developing animals, $\mathrm{O} 2 \mathrm{~A}^{\text {neonatal }}$ progenitor cells are thought to migrate within white matter and to develop into oligodendrocytes (LeVine and Goldman, 1988; Reynolds and Wilkins, 1988; Hardy and Reynolds, 1991; Levine et al., 1993). Oligodendrocytes undergo continuous tumover in adult animals (Kaplan and Hinds, 1980; McCarthy and LeBlond, 1988) and $\mathrm{O}_{2} \mathrm{~A}^{\text {adult }}$ progenitor cells may function as oligodendrocyte precursors. Thus, it is possible that at least a portion of the NG2positive, $\mathrm{O} 2 \mathrm{~A}^{\text {adult }}$ progenitor cells stimulated to incorporate thymidine at $24-48 \mathrm{hr}$ postlesion or their daughter cells migrate 
away from the lesion site and subsequently differentiate into oligodendrocytes. Since NG2-positive cells in normal adult tissue also incorporate ${ }^{3} \mathrm{H}$-thymidine (Levine et al., 1993), it is difficult to separate the contribution of normal, unreactive cells to the increased incidence of thymidine-labeled cells within white matter from that of reactive cells. However, the cell counts presented above suggest that such a contribution may be minimal since the density of labeled cells in tissue close to but not immediately adjacent to a lesion site in animals pulse labeled at $48 \mathrm{hr}$ postlesion and chased for $30 \mathrm{~d}$ was six times greater than the labeling index within normal tissue subjected to the same pulse-chase labeling paradigm.

In summary, the observations presented here suggest that the NG2-positive, O2A adutt progenitor cells can be considered a reactive cell type within the CNS. In response to injury, these cells incorporate ${ }^{3} \mathrm{H}$-thymidine, increase in number and increase their expression of the NG2 chondroitin-sulfate proteoglycan. The functional consequences of this increased expression of the NG2 PG are unknown. Increased levels of chondroitin-sulfatelike immunoreactivity have been identified within glial scars (McKeon et al., 1991), although the core proteins that carry these immunoreactive glycosaminoglycans have not been identified. The data presented here demonstrate that NG2 is one molecular species of chondroitin-sulfate proteoglycan whose expression is increased within damaged nervous tissue. Whether the expression of other species of chondroitin-sulfate proteoglycans such as neurocam (Rauch et al., 1992) or astrochondrin (Streit et al., 1990) is increased after injury is unknown. Like the extracellular molecule tenascin, whose expression is also increased after injury (Lochter et al., 1991; Laywell et al., 1992), the increased expression of the NG2 PG may have important consequences for the attempts of damaged axons to sprout and regrow (Dou and Levine, 1992).

\section{References}

Armstrong R, Friedrich VL Jr, Holmes KV, Dubois-Dalcq M (1990) In vitro analysis of the oligodendrocyte lineage in mice during demyelination and remyelination. J Cell Biol 111:1183-1195.

Barres BA, Hart IK, Coles HSR, Burne JF, Voyvodic JT, Richardson WD, Raff MC (1992) Cell death and control of cell survival in the oligodendrocyte lineage. Cell 70:31-46.

Barres BA, Schmid R, Sendtner M, Raff MC (1993) Multiple extracellular signals are required for long-term oligodendrocyte survival. Development 118:283-295.

Berry M, Maxwell WL, Logan A, Mathewson A, McConnel P, Ashhurst DE, Thomas GH (1983) Deposition of scar tissue in the central nervous system. Acta Neurochir [Suppl] 32:31-53.

Bignami A, Eng LF. Dahl D. Uyeda CT (1972) Localization of the glial fibrillary acidic protein in astrocytes by immunofluorescence. Brain Res 43:429-435.

Cavanagh JR (1970) The proliferation of astrocytes around a needle wound in the rat brain. J Anat 106:471-487.

David S, Aguayo AJ (1981) Axon elongation into peripheral nervous system "bridges" after central ncrvous systcm injury in adult rats. Science 214:931-933.

Dijkstra CD, Dopp EA, Joling P, Kraal G (1985) The heterogeneity of mononuclear phagocytes in lymphoid organs: distinct macrophage subpopulations in the rat recognized by monoclonal antibodies ED1, ED2 and ED3. Immunology 54:589-599.

Dou C, Levine JM (1992) The NG2 proteoglycan inhibits neurite outgrowth from cerebellar granule neurons. Soc Neurosci Abstr 18: 959.

Egan RA, Vijayan VK (1991) Fibronectin immunoreactivity in neural trauma. Brain Res 568:330-334.

Finkelstein SP, Apostolides PJ, Caday CG, Prosser J, Philips MF, Klagsburn M (1988) Increased basic fibroblast growth factor (bFGF) im- munoreactivity at the site of focal brain injury. Brain Res 460:253259.

Fulton BP, Burne JF, Raff MC (1992) Visualization of O-2A progenitor cells in developing and adult rat optic nerve by quisqualatestimulated cobalt uptake. J Neurosci 12:4816-4833.

Giulian D, Lachman LB (1985) Interleukin-1 stimulation of astrocyte proliferation after brain injury. Science 228:497-499.

Giulian D, Woodward J, Young DG, Krebs JF, Lachman LB (1988) Interleukin-1 injected into mammalian brain stimulates astrogliosis and neovascularization. J Neurosci 8:2485-2490.

Giulian D, Chen J, Ingeman JE, George JK, Noponen M (1989) The role of mononuclear phagocytes in wound healing after traumatic injury to adult mammalian CNS. J Neurosci 9:4416-4429.

Giulian D, Johnson B, Krebs JF, George JK, Tapscott M (1991) Microglial mitogens are produced in the developing and injured mammalian brain. J Cell Biol 112:323-333.

Goldman J (1992) Regulation of oligodendrocyte differentiation. Trends Neurosci 15:359-362.

Hardy R, Reynolds R(1991) Proliferation and differentiation potential of rat forebrain oligodendroglial progenitors both in vitro and in vivo. Development 111:1061-1080.

Hughes SM, Lillien LE, Raff MC, Rohrer H, Sendtner M (1988) Ciliary neurotrophic factor induces type-2 astrocyte differentiation in culture. Nature 335:70-73.

Ip NY, Wiegand SJ, Morse J, Rudge JS (1993) Injury-induced regulation of ciliary neurotrophic factor mRNA in the adult rat brain. Eur J Neurosci 5:25-33.

Kaplan MS, Hinds JW (1980) Gliogenesis of astrocytes and oligodendrocytes in the neocortical grey and white matter of the adult rat: electron microscopic analysis of light radioautographs. J Comp Neurol 193:711-727.

Latov N, Nilaver G, Zimmerman EA, Johnson WG, Silverman AJ, Defendini R, Cote L (1979) Fibrillary astrocytes proliferate in response to brain injury. Dev Biol 72:381-384.

Laywell ED, Dorries U, Bartsch U, Faissner A, Schachner M, Steindler DA (1992) Enhanced expression of the developmentally regulated extracellular matrix molecule tenascin following adult brain injury. Proc Natl Acad Sci USA 89:2634-2638.

Levine JM (1989) Neuronal influences on glial progenitor cell development. Neuron 3:103-113.

Levine JM, Card JP (1987) Light and electron microscopic localization of a cell surface antigen (NG2) in the rat cerebellum: association with smooth protoplasmic astrocytes. J Neurosci 7:2711-2720.

Levinc JM, Stallcup WB (1987) Plasticity of developing cerebellar cells in vitro studied with antibodies against the NG2 antigen. J Neurosci 7:2721-2731.

Levine JM, Stincone F, Lee YS (1993) Development and differentiation of glial precursor cells in the rat cerebellum. Glia 7:307-321.

LeVine SM, Goldman JE (1988) Spatial and temporal patterns of oligodendrocyte differentiation in rat cerebrum and cerebellum. J Comp Neurol 277:441-455.

Liesi P, Kaakkola S, Dahl D, Vaheri A (1984) Laminin is induced in astrocytes of adult brain by injury. EMBO J 3:683-686.

Lillien LE, Sendtner M, Raff MC (1990) Extracellular matrix-associated molecules collaborate with ciliary neurotrophic factor to induce type-2 astrocyte development. J Cell Biol 111:635-644.

Lindholm D, Castren E, Kiefer R, Zafara F, Thoenen H (1992) Transforming growth factor- $\beta 1$ in the rat brain: incrcase after injury and inhibition of astrocyte proliferation. J Cell Biol 117:395-400.

Lochter A, Vaughan L, Kaplony A, Prochiantz A, Schachner M, Faissner A (1991) $\mathrm{J} 1$ /tenascin in substrate-bound and soluble form displays contrary effects on neurite outgrowth. J Cell Biol 113:1159-1171.

Mathewson AJ, Berry M (1985) Observations on the astrocyte response to a cerebral stab wound in adult rats. Brain Res 327:61-69.

McCarthy GF, LeBlond CP (1988) Radioautographic evidence for slow astrocyte turnover and modest oligodendrocyte production in the corpus callosum of adult mice infused with ${ }^{3} \mathrm{H}$-thymidine. J Comp Neurol 271:589-603.

McKeon RJ, Schreiber RC, Rudge JS, Silver J (1991) Reduction of neurite outgrowth in a model of glial scarring following CNS injury is correlated with the expression of inhibitory molecules on reactive astrocytes. J Neurosci 11:3398-3411.

McKinnon RD, Matsui T, Dubois-Dalcq M, Aaronson SA (1990) FGF modulates the PDGF-driven pathway of oligodendrocyte development. Neuron 5:603-614. 
Milligan CE, Levitt P, Cunningham TJ (1991) Brain macrophages and microglia respond differently to lesions of developing and adult visual system. J Comp Neurol 314:136-146.

Miyake T, Hattori T, Fukada M, Kitamura T, Fujita S (1988) Quantitative studies on proliferative changes of reactive astrocytes in mouse cerebral cortex. Brain Res 451:133-138.

Miyake T, Okada M, Kitamura T (1992) Reactive proliferation of astrocytes studied by immunohistochemistry for proliferating cell nuclear antigen. Brain Res 590:300-302.

Nishiyama A, Dahlin KJ, Prince JT, Johnstone SR, Stallcup WB (1991) The primary structure of NG2, a novel membrane-spanning proteoglycan. J Cell Biol 114:359-371.

Noble M, Murray K, Stroobant P, Waterfield MD, Riddle P (1988) Platelet-derived growth factor promotes division and motility and inhibits premature differentiation of the oligodendrocyte/type- 2 astrocyte progenitor cell. Nature 333:560-562.

Perry VH, Hume DA, Gordon S (1985) Immunohistochemical localization of macrophages and microglia in the adult and developing mouse brain. Neuroscience 15:313-326.

Peters A, Palay SL, Webster H (1976) The fine structure of the nervous system. Philadelphia: Saunders.

Rauch U, Karthikeyan L, Maurel P, Margolis U, Margolis RK (1992) Cloning and primary structure of neurocam, a developmentally regulated, aggregating chondroitin-sulfate proteoglycan of brain. J Biol Chem 267:19536-19547.

Reier PJ, Stensaas LJ, Guth L (1983) The astrocytic scar as an impediment to regeneration in the central nervous system. In: Spinal cord reconstruction (Rao CC, Bunge RP, Reier PJ, eds), pp 163-195. New York: Raven.

Reyners H, Gianfelici de Reyncrs E, Maisin JR (1982) The beta astrocyte: a newly recognized radiosensitive glial cell type in the cerebral cortex. J Neurocytol 11:967-983.

Reyners H, Gianfelici de Reyners E, Retgniers L, Maisin JR (1986) A glial progenitor cell in the cerebral cortex of the adult rat. J Neurocytol 15:53-61.

Reynolds R, Wilkin GP (1988) Development of macroglial cells in rat cerebellum. II. An in situ immunohistochemical study of oligodendroglial lineage from precursor to mature myelinating cell. Development 102:409-425

Richardson WD, Pringle N, Mosley MJ, Westermark B, Dubois-Dalcq $M$ (1988) A role for platelet-derived growth factor in normal gliogenesis in the central nervous system. Cell 53:309-319.

Stallcup WB, Beasley L (1987) Bipotential glial precursor cells of the optic nerve express the NG2 proteoglycan. J Neurosci 7:2737-2744.

Stallcup WB, Beasley L, Levine JM (1983) Cell-surface molecules that characterize different stages in the development of cerebellar interneurons. Cold Spring Harbor Symp Quant Biol 48:761-774.

Streit A, Faissner A, Gehrig B, Schachner M (1990) Isolation and biochemical characterization of a chondroitin-sulfate proteoglycan expressing the L5 carbohydrate epitope. J Neurochem 55:1494-1 506.

Streit WJ, Graeber MB, Kreutzberg GW (1988) Functional plasticity of microglial: a review. Glia 1:301-307.

Takamiya Y, Kohsaka S, Toya S, Otani M, Tsukadea Y (1988) Immunohistochemical studies on the proliferation of reactive astrocytes and the expression of cytoskeletal proteins following brain injury in rats. Brain Res 38:201-210.

Topp KS, Faddis BT, Vijayan VK (1989) Trauma-induced proliferation of astrocytes in the brains of young and aged rats. Glia 2:201211 .

Vaughn JE, Peters A (1986) A third glial cell type: an electron microscopic study. J Comp Neurol 133:269-288.

White JD, Olchovsky D, Kershaw M, Berelowitz M (1990) Increased hypothalamic content of preproneuropeptide $Y$ messenger ribonucleic acid in streptozotocin-diabetic rats. Endocrinology 126:756-772.

Wolswijk G, Noble M (1989) Identification of an adult-specific glial progenitor cell. Development 105:387-400.

Wolswijk G, Riddle PN, Noble M (1991) Platelet-derived growth factor is mitogenic for O-2A adult progenitor cells. Glia 4:495-503.

Wren D, Wolswijk G, Noble M (1992) In vitro analysis of the origin and maintenance of $\mathrm{O} 2 \mathrm{~A}^{\text {adult }}$ progenitor cells. J Cell Biol 116:167176. 